\title{
324 Building Safety Analysis Report Supplement
}

by

A. O. Dodd

N. G. Wittenbrock

June 24,1977

Prepared for the Energy Research and Development Administration under Contract EY-76-C-06-1830 


\title{
NOTICE
}

This report was prepared as an account of work sponsored by the United States Covernment. Neither the United States nor the Energy Research and Development Administration, nor any of their employees, nor any of their contractors, subcontractors, or their employees, makes any warranty, express or implied, or assumes any legal liability or responsibility for the accuracy, completeness or usefulness of any information, apparatus, product or process disclosed, or represents that its use would not infringe privately owned rights.

The views, opinions and conclusions contained in this report are those of the contractor and do not necessarily represent those of the United States Government or the United States Energy Research and Development Administration.

\author{
PACIFIC NORTHWEST LABORATORY \\ operated by \\ BATTELLE \\ for the \\ ENERCY RESEARCH AND DEVELOPMENT ADMINISTRATION \\ Under Contract EY-76-C-06-1830
}

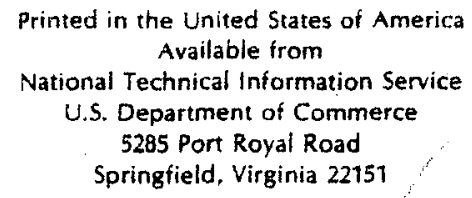

Price: Printed Copy $\$$

; Microfiche $\$ 3.00$

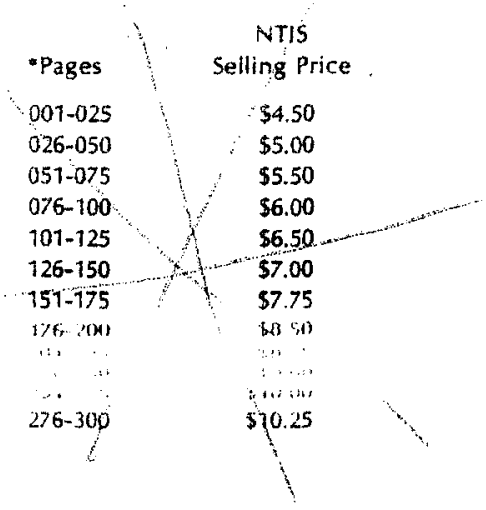




\section{DISCLAIMER}

This report was prepared as an account of work sponsored by an agency of the United States Government. Neither the United States Government nor any agency Thereof, nor any of their employees, makes any warranty, express or implied, or assumes any legal liability or responsibility for the accuracy, completeness, or usefulness of any information, apparatus, product, or process disclosed, or represents that its use would not infringe privately owned rights. Reference herein to any specific commercial product, process, or service by trade name, trademark, manufacturer, or otherwise does not necessarily constitute or imply its endorsement, recommendation, or favoring by the United States Government or any agency thereof. The views and opinions of authors expressed herein do not necessarily state or reflect those of the United States Government or any agency thereof. 


\section{DISCLAIMER}

Portions of this document may be illegible in electronic image products. Images are produced from the best available original document. 
324 BUILDING

SAFETY ANALYSIS REPORT

SUPPLEMENT

by

A. 0. Dodd

N. G. Wittenbrock

June 24,1977

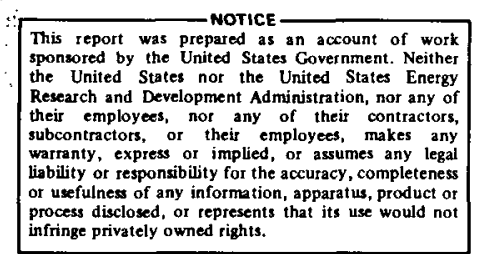

infringe privately owned rights.

\section{BATTELLE \\ PACIFIC NORTHWEST LABORATORIES \\ RICHLAND, WASHINGTON 99352}


TABLE OF CONTENTS

1.0 INTRODUCTION

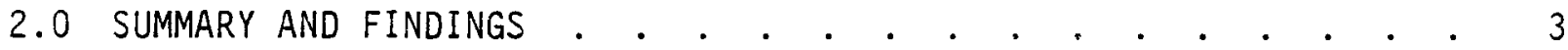

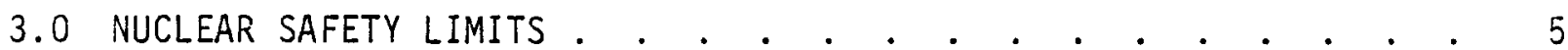

3.1 Fissionable Materials Limits . . . . . . . . . . . 5

4.0 PROCESS DESCRIPTION. . . . . . . . . . . . . . . . . . . 7

4.1 Commercial Nuclear Waste Preparation . . . . . . . . 7

4.2 High Level Liquid Waste Vitrification . . . . . . . . 11

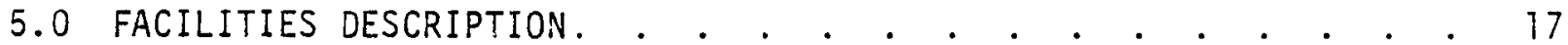

5.1324 Building - General . . . . . . . . . . . . 17

5.2 B-Cell Renovation. . . . . . . . . . . . . . . 17

5.3 Air Lock Cell Load-Out Port . . . . . . . . . . . 19

5.4 Air Lock Cell Wall-Mounted Jib Hoist . . . . . . . . 19

5.5 Cask Handling Area Facilities. . . . . . . . . . . 19

5.6 Secondary Containment for Piping. . . . . . . . . 20

5.7 324-325 Interbuilding Pipeline . . . . . . . . . . 20

5.8324 Building - 300 Area Waste System Modifications. . . . 23

5.9 Site Protected Area . . . . . . . . . . . . . 25

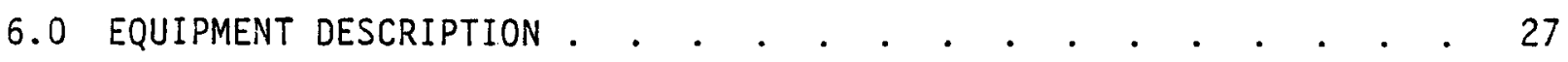

6.1 Existing Equipment . . . . . . . . . . . . . . 27

6.2 Supplemental Equipment . . . . . . . . . . . . . . 27

E.3 Equipment Modifications. . . . . . . . . . . . . 28 
6.4 Equipment Instrumentation. . . . . . . . . . . . 30

6.5 Development Modifications . . . . . . . . . . . . 30

7.0 ORGANIZATION AND ADMINISTRATIVE CONTROLS. . . . . . . . . . . . . 33

7.1 Organization . . . . . . . . . . . . . . . . 33

7.2 Administrative Controls. . . . . . . . . . . 33

8.0 SAFETY ANALYSIS . . . . . . . . . . . . . . . . . . 39

8.1 General . . . . . . . . . . . . . . . 39

8.2 Control of Off-Standard Conditions . . . . . . . . 39

8.3 Criticality Safety . . . . . . . . . . . . . 40

8.4 Routine Environmental Releases . . . . . . . . 45

8.5 Cask Shipments. . . . . . . . . . . . 48

8.6 Hypothetical Accidents. . . . . . . . . . . 48

REFERENCES. . . . . . . . . . . . . . . 57 


\section{FIGURES}

1 Commercial Nuclear Waste Preparation Flowsheet - 324 zuilding High-Level Cells. . . . . . . . . . . . . . 8

2 Commercial Nuclear Waste Solidification Flowsheet - 324 Building High-Level Cells. . . . . . . . . . . 12

$3 \quad 324$ Building Radiochemical Engineering Cells . . . . . . 18

4 Plot Plan for 300 Area Protected Area. . . . . . . . . 21

5 Flowsheet and Material Balance 324 B-Cell Dissolver System. 29

ó B-Cell Equipment Plan View . . . . . . . . . . . . 31

7 Commercial Nuclear Waste Vitrification Project Organization . 35

\section{TABLES}

1 Typical Composition of Spray Caiciner Feed . . . . . . 14

2 Control of Off-Standard Conditions . . . . . . . . . 40

3 UNH Criticality Safety Parameters . . . . . . . . . 43

4 Estimated Environmental Doses. . . . . . . . . . . . . 46

5 Comparison of Calculated Doses From the Waste Preparation Task With Those From Past Hanford Operations and With Proposed EPA Criteria... . . . . . . . . . . . 47

6 Ventilation System Failure Dose Estimates. . . . . . . 53

7 Cask/Fuel Unloading Accident Dose Estimates . . . . . . 56 


\subsection{INTRODUCTION}

An engineering scale demonstration of the solidification and packaging of high level wastes from reprocessing LWR fuel will be conducted by PNL in the hot cell facilities of the 324 and 325 Buildings. The Commercial Nuclear Waste Vitrification Project (CNWVP) consists of two tasks of the Commercial High-Level Waste Fixation Program:

- Task 6 - Commercial Nuclear Waste Preparation

- Task 5 - Radioactive Demonstration of Vitrification

The demonstration involves the preparation of actual high-level liquid waste (HLLW) from spent fuel elements discharged from commercial nuclear power reactors. Conversion of the HLLW to a vitreous solid and packaging the solid in stainless steel canisters will complete the demonstration. For the waste preparation task the processing rate will be one metric ton of uranium (1000 kg, 1 tonne) per month as LWR spent fuel. The equipment for solidification of the waste can be operated at processing rates up to an equivalent of one metric ton of uranium per day.

Briefly, the process consists of the following steps:

- Receiving spent fuei elements from commercial power reactors at the 324 Building Radiochemical. Engineering Cel1s, brought by truck in DOT-approved shipping casks.

- Transferring the shipping casks into the 324 Building Radiochemical Engineering Cells.

- Unloading the fuel elements from the casks into thimbles.

- Disassembling the fuel elements.

- Shearing the fuel rods into short lengths.

- Dissolving the spent fuel out of the short lengths of cladding hulls.

- Transferring the dissolver solution via pipeline from the 324 Building to the 325-A Building High Level Radiochemical Cells (alternate systems are to transfer chopped fuel or dissolver solution via approved casks on trucks). 
- Separating the HLLW, a waste uranium stream, and the contained plutonium using basic Purex and anion exchange processes in 325-A Building.

- Transferring the HLLW to 324 Building via pipeline (or by an approved shielded cask on truck).

- Vitrifying and packaging the HLLW by methods previously studied by Battelle.

Part of the Waste Preparation Task will be performed in the 324 Building Radiochemical Engineering Cells. These operations are the receipt of irradiated LWR fuel elements, storing irradiated elements, disassembling fuel element bundles, shearing the fuel rods, and dissolving the spent fuel. A11 of these processing operations will be performed in B-Cell of the 324 Building.

In the Radioactive Demonstration of the Vitrification Task, the activities to be performed in 324 Building will be essentially the same as those previously conducted in the Waste Solidification Engineering Prototypes (WSEP) Program which are described in the 324 Building SAR. (1) Since Task 5 will introduce no significant new hazards or unreviewed safety questions, its activities are not analyzed in detail in this Supplement to the 324 Building SAR. Task 6 operations, however, are new to the 324 Building.' Its activities are discussed in detail in this supplement, and a safety analysis of the operation is presented.

Before the demonstration phase of the CNWVP is started, a number of safety related analyses and documents will be approved. They are:

- Criticality Safety Analysis of the Final Design

- Criticality Safety Specifications

- Process Specifications

- Safe Operating Procedures

- Emergency Procedures

- Training Programs

- Diversion Path Analysis

- Operations Safety Requirements, and

- Operational Readiness Report 


\subsection{SUMMARY AND FINDINGS}

Process engineering designs, major equipment and plant facilities to be utilized in commercial nuclear waste preparation and vitrification in the 324 Radiochemical Engineering Building are reviewed with regard to accident potential and consequences. This Safety Analysis Report Supplement meets the review and reporting requirements of USERDA Manual Chapter RL0530 for planned operations in non-reactor nuclear facilities, when operations introduce the possibility of a new kind of accident not previously analyzed in the SAR and a change of existing Nuclear Safety Limits is required.

Engineering flow diagrams, planned new equipment and instrumentation for the fuel chopping, dissolving and solids handling steps of the waste preparation process are described. Included are activities accomplished or planned for updating facilities and services as needed. Plans for implementing the ERDA policy of providing secondary containment for process lines, vessels and facilities handling high-level radioactive wastes are reviewed. Organizational function and responsibility are reviewed and updated in consideration of the present sharing of the facility by the PNL and HEDL components.

Nuclear safety limits appropriate for the handling, storing and processing of fissionable materials characteristic of spent LWR fuels are established for the waste preparation phase of the CNWVP. Accidents are postulated and consequences evaluated for a ventilation system failure and a cask/fuel unloading accident. Environmental impact of routine operation is discussed.

This Safety Analysis Report Supplement compares calculated environmental doses anticipated from the CNWVP routine operations with the average doses from past waste management operations conducted at the Hanford Project and finds them to be significantly less. Also, the calculated CNWVP environmental doses are found to be far below presently applicable ERDA standards and standards proposed by the EPA for nuclear power operations. 
Evaluating the dose estimates from CNWVP postulated accidents, one finds them of the same order of magnitude or less than the doses from past Hanford waste management operations. The doses to the offsite individual at maximum radiological risk would be slightly higher than those for routine operations, and equal to or less than those from past Hanford waste management operations. But even in the accident cases, the anticipated exposure doses would be less than applicable regulatory standards for routine nuclear power operations.

In the Detailed Accident Analysis for the High Level Waste Preparation Task of the CNWVP, the project design was reviewed to assure that no inherentiy unsafe conditions exist which could conceivably constitute significant environmental hazards. In this supplement those postulated accident situations, as well as routine operations, applicable to 324 Building have been evaluated as to potential consequences. The design and operational plans for the CNWVP in 324 Building are judged not to represent an undue environmental risk from routine operations or from credible though unlikely accident situations.

Exposures and releases of radionuclides during normal, routine operations of the CNWVP will be within the limits of ERDA Manual Chapter 0524. Routine operations of the CNWVP in the 324 Building will not have an adverse effect on HEDL operations in the 324 Building. Only in the cask handling area, where careful scheduling of deliveries and shipments for the two organizations will be necessary, could inconvenience to HEDL result from inadvertant contamination spills. Accident analyses indicate that potential interruptions to other operations in the 300 Area from credible though unlikely accidents represent an acceptably low risk. 


\subsection{NUCLEAR SAFETY LIMITS}

This section of the 324 Building SAR Supplement is concerned only with the Nuclear Safety Limits applicable to the Radiochemical Engineering Cells and associated space assigned to PNL. It modifies the limits previously established for the WSEP in Section III.A., BNWL-CC-2028. (1) The limits are changed to allow the storage and processing of inventories of fissionable material in the Radiochemical Engineering Cells greater than a minimum critical mass.

The Nuclear Safety Limits stated in this section are binding. They are to be implemented in Criticality Safety Specifications. All fissionable material operations shall be controlled by engineered safeguards and procedural controls so that a double contingency policy is operative (i.e., at least two unlikely, independent and concurrent accidents, failures or limit violations must occur before criticality is possible).

Fissionable materials may be processed in any physical or chemical form. Specification limits shall be established at fractions of the critical parameters for the subject material, providing safety margins commensurate with any characteristic uncertainties. Other restrictions given in this supplement are examples of those set forth in Criticality Safety Specifications or Radiation Work Procedures, presented for descriptive purposes, and subject to change within these Limits.

\subsection{Fissionable Materials Limits}

\subsubsection{Initial Enrichment}

Irradiated fuel elements processed in the CNWV Project sha11 have had an initial enrichment before irradiation no greater than $3.5 \% 235 \mathrm{U}$.

\subsubsection{Mass Control}

Fissionable material operations based solely upon mass control shall be batch limited to $45 \%$ of a critical mass. Critical mass shall be determined by the physical, chemical and isotopic form or fixed geometric arrangement of the fissionable material, assuming full water reflection. 


\subsubsection{Geometry Control}

Fissionable material operations based upon geometry control shall employ vessels which are dimensionally 1 imited to $75 \%$ of the critical volume, $85 \%$ of the critical slab thickness, or $85 \%$ of the critical diameter, as appropriate. Critical dimensions shall be determined assuming optimum moderation and ful1 water reflection.

\subsubsection{Concentration Control}

Concentration control shall not be used as a basis for establishing double contingency protection on an operation involving solutions of fissionable materials. However, where concentration control is used to provide an additional contingency of protection (beyond two contingencies), the concentration shall be controlled so that the neutron multiplication constant $\left(K_{\infty}\right)$ will not exceed 0.95 .

\subsubsection{Fixed Storage Arrays}

Fixed storage arrays and fixed process equipment shall be limited by either:

- mass controls specified in Limit 3.1.2,

- geometry controls specified in Limit 3.1.3, or

- the $K_{\text {eff }}$ of the array or equipment shall not exceed 0.95 with all storage positions or process vessels loaded to the specified limit and with optimum interspersed moderation and credible reflection.

\subsubsection{Spacing Between Batches}

Spacing between batches of fissionable materials, process or other vessels containing fissionable materials, and fissionable material being transported past other fissionable material, shall support the two contingency policy and shall be established by a technical analysis. Fissionable materials not separated by specified safe spacing shall be considered as parts of the same batch. 


\subsection{PROCESS DESCRIPTION}

\subsection{Commercial Nuclear Waste Preparation}

The processing approach of the waste preparation task is the same as that planned for commercial fuel reprocessing piants, through the first solvent extraction cycle of the Purex process. Figure 1 depicts schematically the flowsheet for the process operations in the 324 Building HighLevel Cells. The 324 Building B-Cell dissolver system is designed for batch operation. All of the equipment is designed for the normal batch size of $100 \mathrm{~kg}$ of uranium. Batch identity is maintained in 324 Building, including the batch transfer of dissolver solution to the 325-A Building.

\subsubsection{Spent Fuel Receipt and Preparation}

Irradiated LWR fuel elements will be transported from the suppliers to PNL in DOT/NRC licensed shipping casks (NAC-1 or NFS-4) and received at the 324 Building Truck Lock and Cask Handling Area. By use of the 30-ton bridge crane, the 25-ton cask will be removed from the offsite transporter while in a horizontal position and placed on a tipping cradle. (A special bail will permit horizontal handling of the cask.) The cask will then be raised to the vertical position, placed on the existing Cask Handling Area - Air Lock Transfer Device, and moved into the Air Lock Cell. Then a lifting bail will be installed on the cask lid and the bolts holding this lid will be removed. At this time, personnel will evacuate the Air Lock and the shielding door will be closed.

Removal of the cask lid and fuel from the cask will be performed remotely. Existing shielded viewing windows and television systems will be used for observing these operations. The cask 1 id will be removed with the existing Air Lock crane. A wall-mounted jib hoist will be used for removing the fuel bundle from the cask and placing it in a handling thimble. The thimble containing fuel will be transported to $\mathrm{B}-\mathrm{Ce} 11$ with the existing $B-C e 11$ crane for fuel storage and/or shearing. A nine space fuel storage rack in B-Cell will provide storage for up to three tonnes of fuel. To prevent unnecessary fuel handling, the rack will allow storing the fuel in 


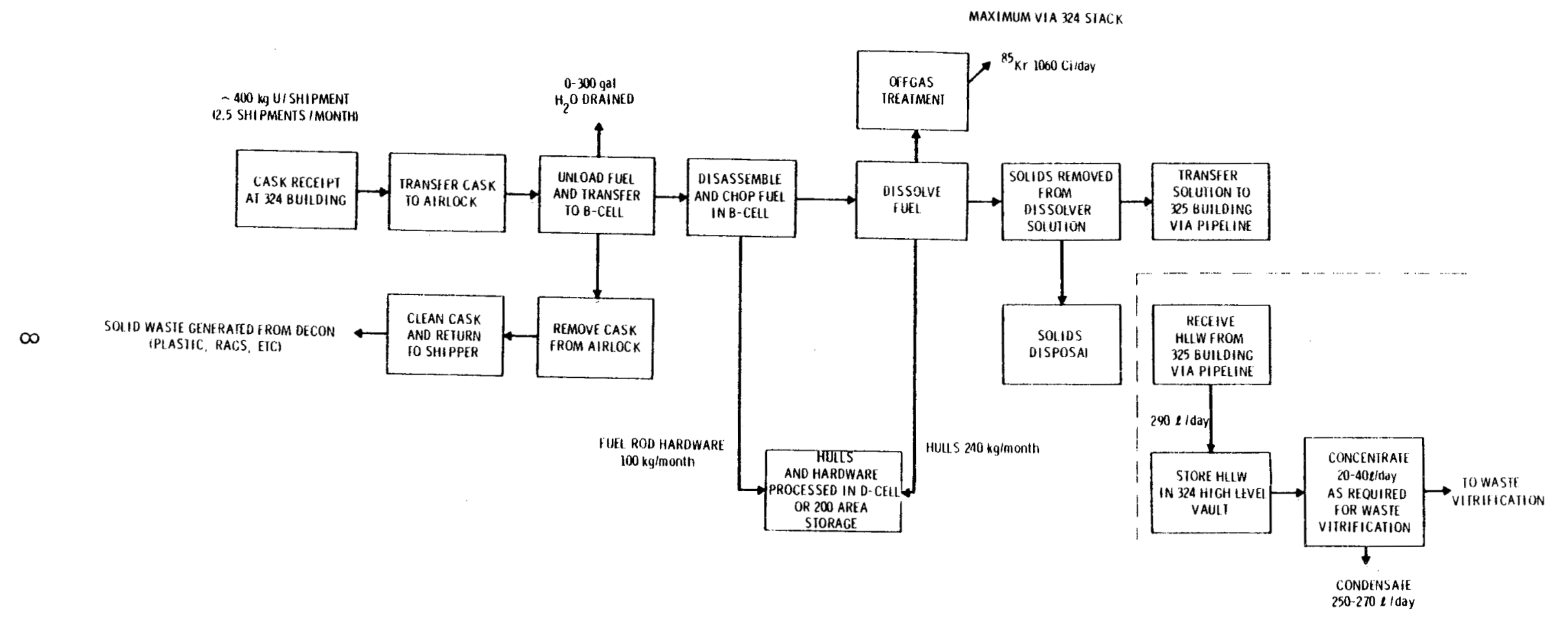

FIGURE 1. Commercial Nuclear Waste Preparation Flowsheet - 324 Building High-Level Cells (1 MTU/Month Rate -- $100 \mathrm{~kg} /$ Day Maximum) 
the handling thimble. The empty cask will then be closed, removed from the Air Lock Cell, decontaminated, placed on the offsite transporter and released.

In B-Cell the fuel bundle and the thimble will be removed from the storage rack and positioned horizontally on a disassembly tray. The upper water block or other hardware will be removed from the fuel bundles. Then the rods will be fed (singly or in multiples) through a shear and chopped into 1-to 2-in.-long pieces. These fuel rod pieces and fines will fall into a perforated basket within the dissolver. The basket will facilitate removal of the cladding hulls after fuel dissolution. The fuel cladding will be sealed in cans, passed through a shielded load-out port in the Air Lock wall into a Dry Waste Cask ${ }^{(2)}$ and transported to the 200 Areas for storage in caissons as trans-uranium (TRU) waste. The fuel bundle hardware will be placed in solid waste boxes and buried in the 200 Areas.

\subsubsection{Fuel Dissolution}

The chopped fuel will be dissolved in nitric acid. Successive steps of dissolution, hulls leaching, and hulls rinsing will be employed. One dissolver will achieve the desired throughput (100 kg uranium/batch, one tonne/month) with reasonable chopping-dissolution-leach-rinse cycles. An operating temperature of $90-95^{\circ} \mathrm{C}$ will allow efficient dissolution and at the same time will minimize the reflux of water. The dissolver will be sparged with air to aid in attaining maximum evolution of iodine into the offgas stream. The cladding hulls will be used in 324 Building for research and development or transferred in the Dry Waste Cask ${ }^{(2)}$ to the 200 Areas for storage.

\subsubsection{Dissolver Offgas Treatment}

The gases leaving the dissolver, after mixing with the vessel vent offgas stream, will pass through a demister and condenser to be cooled to $\sim 60^{\circ} \mathrm{C}$ to lower the water content. They will then pass through a heater and silver zeolite adsorption bed for removing $>9.9 \%$ of the volatilized iodine. The gas stream will then pass through the existing. B-Cell packed scrubber column and another condenser to further reduce the concentration of tritiated water vapor. Then the gas stream will pass through another heater and HEPA filter, and discharge from a blower to the Building ventilation exhaust 
system (one HEPA filter in series with an impregnated activated charcoal filter) before release from the stack. The ${ }^{85} \mathrm{Kr}$ will not be removed but will be discharged to the atmosphere. (3)

\subsubsection{Dissolver Solution Clarification and Transfer to 325-A Building}

Dissolver solution, from the primary system located in 324 Building B-Cell, will be filtered for removal of large particles ( $>100$ microns) that are difficult to keep in suspension and which would cause problems in valves, steam jets, sampling systems, etc. The filtered solids will be discarded with the leached hulls. The smaller particles pass through the filters and remain in the process stream.

The filtered dissolver solution will be collected in the dissolver solution holding tank. In this tank the concentration will be adjusted to approximately $375 \mathrm{~g}$ U/liter. From the holding tank the dissolver solution will be transferred by air lift to a head pot which will supply the 3/8-inch stainless steel interbuilding transfer pipeline. This head pot will be at an elevation slightly lower than the receiving tank in the 325-A Building. Block connectors in 325-A Building C-Cell will be used to connect and disconnect the pipeline to the dissolver solution vacuum tank in the 325-A Building basement. Transfer of the dissolver solution from 324 Building to the 325-A Building will be by vacuum. An acid flush solution will be sent through the pipeline after each dissolver solution transfer. In the event the interbuilding pipeline is out of service, transfer of dissolver solution by approved shielded cask may be accomplished. (2)

\subsubsection{Receipt of HLLW From 325-A Building}

The aqueous waste stream from the HA Column of the solvent extraction system wi11 be the desired product of Task 6, HLLW. It will contain essentially all the nonvolatile fission products and the transuranium elements other than plutonium, and small amounts of uranium and plutonium. It also will contain the bulk of the tritium (as HTO) and a small portion of the iodine. The HLLW will be transferred via a 3/4-inch pipe within the interbuilding transfer pipe line, or by cask, ${ }^{(2)}$ from 325-A Building to the HLLW storage tank in the 324 Building. A steam jet in 324 Building will provide 
motivation for the transfer by pulling a vacuum on the line. When all high-level liquid waste is transferred, water or acid from the 325-A Building will flush the 1 ine. Any leakage from the transfer line (into a 2-inch stainless steel containment pipe) would be detected by instrumentation continuously monitoring the radioactivity of the off gas flowing inside the 2-inch pipe; the activity of this offgas stream will be recorded in the control rooms in both the 324 and 325-A Buildings.

The aqueous uranium and plutonium product stream from the HC Column of the solvent extraction system in 325-A Building will be steam-stripped (to remove organics) and concentrated. The condensate will be collected and recycled within 325-A Building. As an option it may be transferred by the interbuilding pipeline to the 324 Building for concentration and disposal via the 300 Area radioactive liquid waste system.

\subsubsection{Backup Dissolution Operation}

An alternative system for chopped fuel dissolution will provide for redundancy of capability or for special operations. This system will utilize the fuel chopping equipment in 324 Building B-Ce11, followed by cask transfer (2) of the chopped fuel from 324 to 325-A Building, and a pair of dissolvers installed in 325-A Building $\mathrm{C}-\mathrm{Cell}$. The cladding hulls will be cask transferred back to 324 Building for research and development or to the 200 Areas for storage in caissons. The balance of the operations will be essentially identical to those described above.

\subsection{High Level Liquid Waste Vitrification}

Figure 2 depicts schematically the process flowsheet for the calcination, vitrification and offgas treatment of the HLLW. This flowsheet is essentially the same as that used during the 1970 WSEP demonstrations of the feasibility of solidifying radioactive wastes with a spray calciner/incan melter system. ${ }^{(4)}$ The only addition is a quench scrubber--the first treatment step in the offgas system downstream of the porous stainless steel filters in the spray calciner. 


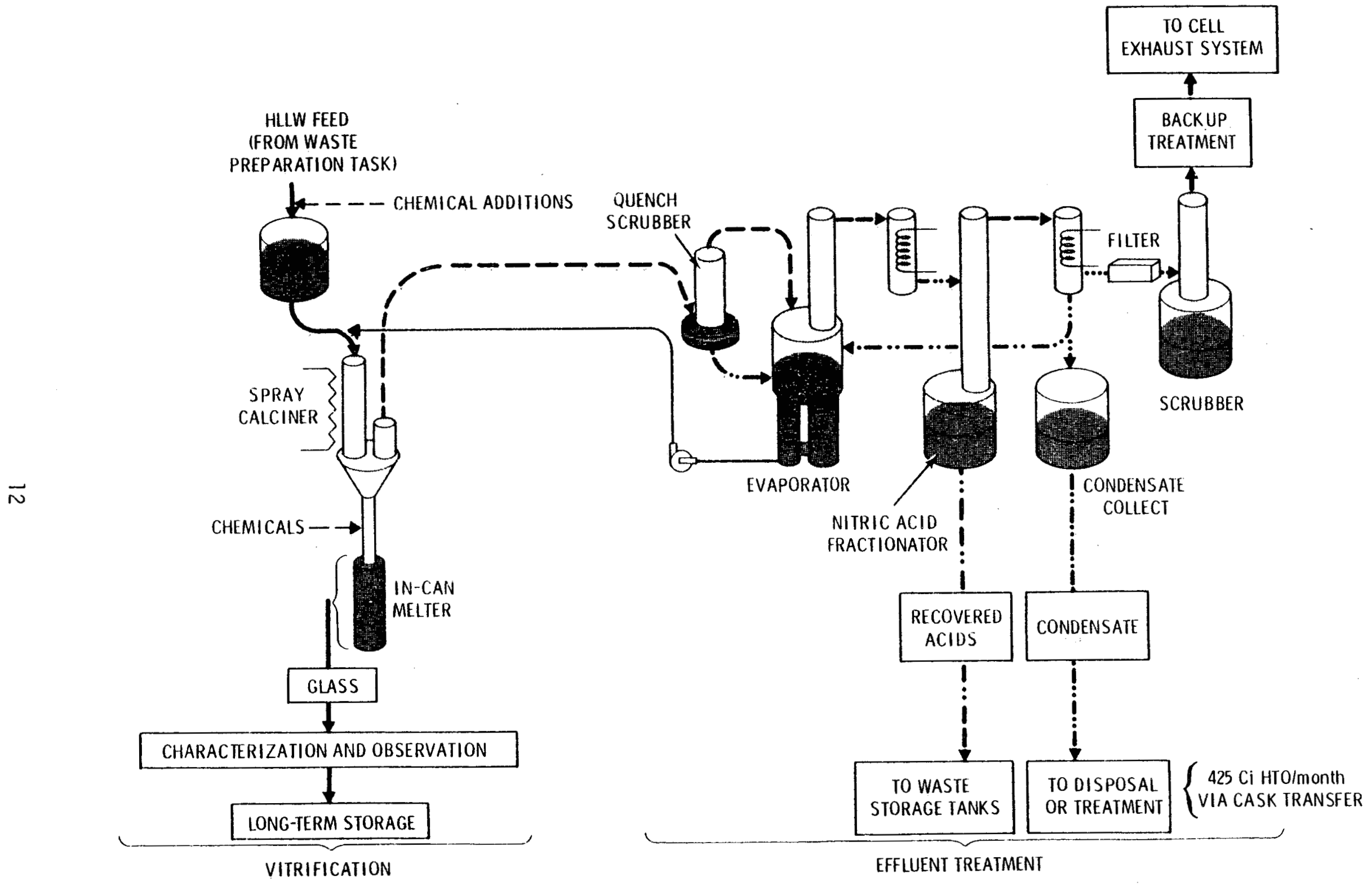

FIGURE 2. Commercial Nuclear Waste Solidification Flowsheet - 324 Building High-Level Cells (1 MTU Waste/Day Maximum Rate) 


\subsubsection{Spray Calcination}

During spray calciner operation, HLLW will be metered and pumped to the spray calciner at a pressure of 1 to $2 \mathrm{~atm}$. Table 1 gives typical composition of spray calciner feed (HLLW less volatiles removed during concentration). The solution will be pneumatically atomized in an internal mix nozzle and sprayed into the top center of the cylindrical calcination chamber. The atomized liquid waste will be sequentially concentrated, dried, and calcined as it falls through the heated calcination chamber.

The chamber walls will be heated to about $700^{\circ} \mathrm{C}$ by an external multizone resistance furnace. Inside the chamber sufficient heat will be transferred to the droplets by a combination of radiation and convection to produce a calcine typical1y $1-4 \%$ moisture and 2-20\% nitrate. Drying of the droplets will occur in a fraction of a second, thus minimizing volatilization of radionuclides. Deposition of solids on heat transfer surfaces within the calciner will be prevented by periodic operation of side-mounted vibrators.

On passing through the calcination chamber, water vapor and atomizing afr will entrain 15 to $50 \%$ of the calcine particies. More than $99.9 \%$ of the particulates will be de-entrained by porous stainless steel filters. The powder collected on the filters will be periodically removed by a pulse of blowback air. After this the powder will fall into the lower calciner cone and be discharged into the canister along with the calcine that falls directly from the calcination chamber.

\subsubsection{In-Can Melting}

Glass frit will be metered directly into the lower cone of the calciner at a rate proportional to the calcine generation rate. This will provide for the formation of silicate glass in a canister located within the in-can melter furnace, operated at $1000-1050^{\circ} \mathrm{C}$. Furnace containment design wi11 prevent gross discharge of dust or materials to the cell in the event of any canister problem. When filled, the canister will be removed from the in-can melter furnace, sealed by welding, leak tested, and transferred to the canister storage rack. 
TABLE 1. Typical Composition of Spray Calciner Feed

BASIS: MTU CHARGE TO REACTOR

Reference PWR; 3.3\% enriched U; 30 MW power; 33,000 MWd/MTU burnup; one year after discharge; average 500 liters calciner feed/MTU

Element Grams/MTU Curies/MTU Grams/Liter Moles/Liter

$\begin{array}{lcccc}\mathrm{Rb} & 3.34 \mathrm{E}+2 & 6.63 \mathrm{E}-4 & 6.68 \mathrm{E}-1 & 7.81 \mathrm{E}-3 \\ \mathrm{Sr} & 8.83 \mathrm{E}+2 & 8.10 \mathrm{E}+4 & 1.77 \mathrm{E}+0 & 2.02 \mathrm{E}-2 \\ \mathrm{Y} & 4.66 \mathrm{E}+2 & 8.83 \mathrm{E}+4 & 9.32 \mathrm{E}-1 & 1.05 \mathrm{E}-2 \\ \mathrm{Zr} & 3.67 \mathrm{E}+3 & 2.79 \mathrm{E}+4 & 7.34 \mathrm{E}+0 & 8.05 \mathrm{E}-2 \\ \mathrm{Nb} & 1.51 \mathrm{E}+0 & 6.00 \mathrm{E}+4 & 3.02 \mathrm{E}-3 & 3.25 \mathrm{E}-5 \\ \mathrm{Mo} & 3.46 \mathrm{E}+3 & -- & 6.92 \mathrm{E}+0 & 7.22 \mathrm{E}-2 \\ \mathrm{TC} & 8.41 \mathrm{E}+2 & 1.43 \mathrm{E}+1 & 1.68 \mathrm{E}+0 & 1.71 \mathrm{E}-2 \\ \mathrm{Ru} & 2.23 \mathrm{E}+3 & 2.77 \mathrm{E}+5 & 4.46 \mathrm{E}+0 & 4.41 \mathrm{E}-2 \\ \mathrm{Rh} & 3.87 \mathrm{E}+2 & 2.77 \mathrm{E}+5 & 7.74 \mathrm{E}-1 & 7.52 \mathrm{E}-3 \\ \mathrm{Pd} & 1.34 \mathrm{E}+3 & 1.11 \mathrm{E}-1 & 2.68 \mathrm{E}+0 & 2.52 \mathrm{E}-2 \\ \mathrm{Ag} & 6.03 \mathrm{E}+1 & 1.56 \mathrm{E}+3 & 1.20 \mathrm{E}-1 & 1.11 \mathrm{E}-3 \\ \mathrm{Cd} & 8.47 \mathrm{E}+1 & 1.18 \mathrm{E}+1 & 1.69 \mathrm{E}-1 & 1.50 \mathrm{E}-3 \\ \mathrm{Te} & 5.66 \mathrm{E}+2 & 6.02 \mathrm{E}+3 & 1.13 \mathrm{E}+0 & 8.86 \mathrm{E}-3 \\ \mathrm{Cs} & 2.68 \mathrm{E}+3 & 2.83 \mathrm{E}+5 & 5.36 \mathrm{E}+0 & 4.03 \mathrm{E}-2 \\ \mathrm{Ba} & 1.44 \mathrm{E}+3 & 9.85 \mathrm{E}+4 & 2.88 \mathrm{E}+0 & 2.10 \mathrm{E}-2 \\ \mathrm{La} & 1.27 \mathrm{E}+31 & 4.32 \mathrm{E}-3 & 2.54 \mathrm{E}+0 & 1.83 \mathrm{E}-2 \\ \mathrm{Ce} & 2.62 \mathrm{E}+3 & 4.56 \mathrm{E}+5 & 5.24 \mathrm{E}+0 & 3.74 \mathrm{E}-2 \\ \mathrm{Pr} & 1.20 \mathrm{E}+3 & 4.55 \mathrm{E}+5 & 2.40 \mathrm{E}+0 & 1.70 \mathrm{E}-2 \\ \mathrm{Nd} & 3.97 \mathrm{E}+3 & 7.36 \mathrm{E}-5 & 7.94 \mathrm{E}+0 & 5.51 \mathrm{E}-2 \\ \mathrm{Pm} & 8.94 \mathrm{E}+1 & 8.31 \mathrm{E}+4 & 1.79 \mathrm{E}-1 & 1.22 \mathrm{E}-3 \\ \mathrm{Sm} & 8.24 \mathrm{E}+2 & 1.25 \mathrm{E}+3 & 1.65 \mathrm{E}+0 & 1.10 \mathrm{E}-2 \\ \mathrm{Eu} & 1.83 \mathrm{E}+2 & 1.20 \mathrm{E}+4 & 3.66 \mathrm{E}-1 & 2.41 \mathrm{E}-3 \\ \mathrm{Gd} & 1.05 \mathrm{E}+2 & 1.22 \mathrm{E}+1 & 2.10 \mathrm{E}-1 & 1.33 \mathrm{E}-3 \\ \mathrm{U} & 4.78 \mathrm{E}+3 & 1.99 \mathrm{E}-2 & 9.56 \mathrm{E}+0 & 4.02 \mathrm{E}-2 \\ \mathrm{~Np} & 4.78 \mathrm{E}+2 & 1.88 \mathrm{E}+1 & 9.56 \mathrm{E}-1 & 4.03 \mathrm{E}-3 \\ \mathrm{Pu} & 1.36 \mathrm{E}+2 & 6.89 \mathrm{E}+2 & 2.72 \mathrm{E}-1 & 1.12 \mathrm{E}-3 \\ \mathrm{Am} & 1.23 \mathrm{E}+2 & 1.25 \mathrm{E}+2 & 2.46 \mathrm{E}-1 & 1.01 \mathrm{E}-3 \\ \mathrm{Cm} & 3.46 \mathrm{E}+1 & 9.63 \mathrm{E}+3 & 6.92 \mathrm{E}-2 & 2.80 \mathrm{E}-4 \\ \mathrm{Tota} \mathrm{ls}: & 34.35 \mathrm{E}+3 & 2.21 \mathrm{E}+6 & 68.6 \mathrm{E}+0 & \\ & & & & \end{array}$




\subsubsection{Calciner Offgas Treatment}

Calciner offgas will contain less than $0.1 \%$ of the nonvolatile feed constituents and up to $2 \%$ of the ruthenium. ${ }^{(4)}$ First the offgas will pass through a new quench scrubber. Subsequently the gases will pass through the de-entrainment section of the evaporator, a condenser, the fractionation tower of an acid fractionator (for nitric acid recovery), another condenser, an air heater, a HEPA filter, a packed scrubber, condenser, heater, and HEPA filter prior to being released to the building offgas, which includes one more HEPA filter and charcoal adsorber. The 324 Building stack monitoring system includes monitors for $\beta / \gamma, \alpha$, iodine, and krypton. In addition, there are samplers for particulates, iodine, and tritium (both HT and HTO). With this efficient and redundant offgas cleanup system, the offgas discharged from the vitrification process system will contain negligible particulate activity. Recovered acids will be directed to waste storage tanks. Condensate from the acid fractionator, containing up to $425 \mathrm{Ci}{ }^{3} \mathrm{H}$ per month as HTO, will be directed to disposal or further treatment.

\subsubsection{Radioactive Demonstration}

Canisters are to be filled with vitrified waste formed by processing HLLW/ILLW at feed volumes of 800 and 500 l/MTU. They will be fabricated of $304 \mathrm{~L}$ stainless steel and instrumented with thermocouples, etc., to obtain sufficient data for production plant design determination. The 8-in. and 12-in. dia., 8-ft long canisters from the vitrification process will contain the principal fission product radionuclides from $\sim 1$ and $\sim 2$ MT respectively of processed spent LWR fuel. The canisters of silicate glass will be stored in the 324 Building for observation and characterization, in accord with requirements of Task 4 (Product Characterization) of the Commercial High-Level Waste Fixation Program, for an extended period before ultimate disposat.

Existing storage facilities for canisters are available in B-Cell. Fourteen canister-shaped compartments (seven 8-in. diameter and seven 12-in. diameter) allow potential storage of nearly 21 MTU waste ( 2 yr inventory) 
in glass. Additional storage is available in A-Cell, where over 30 canisters of waste glass from previous WSEP operations are presentiy located. Some of these canisters will be removed to provide additional storage. 


\subsection{FACILITIES DESCRIPTION}

\subsection{Building - General}

The feasibility of solidifying radioactive wastes on an engineering scale was demonstrated by $1970^{(4)}$ in the 324 Building Radiochemical Engineering Cells (Figure 3 ). Thorough descriptions of the Building's principal facilities, in support of the above operations, were presented in the Safety Analysis Report, and need not be repeated here. However, certain modifications of these facilities are necessary for the current CNWV and will be discussed in the following paragraphs.

\subsection{B-Cell Renovation}

Following operations under radioactive conditions in 1966-1970 during the WSEP program, B-Ce11 was put in standby condition. (5) The process equipment for those operations still remains in place, most of it being the same or prototypical of current design. In February, 1975, renovation of B-Cell began under the Radioactive Demonstration Task. Cell modifications for the CNWVP, already accomplished or to be completed before start-up, include:

- installation of a new (Halon) fire protection system,

- complete checkout and updating of all electrical, piping and instrumentation systems, including calciner and melter furnaces,

- installation of additional shielded viewing windows for upper elevations,

- installation of a cell sleeve for frit addition to the melter,

- installation of fuel delivery, disassembly, and chopping systems,

- installation of a fuel dissolver with associated hull rinse, chemical addition system, and offgas treatment system,

- installation of a data acquisition system.

An equipment checkout run with acid feed was completed successfully in January 1976 to verify operability of the existing equipment in B-Cell. 

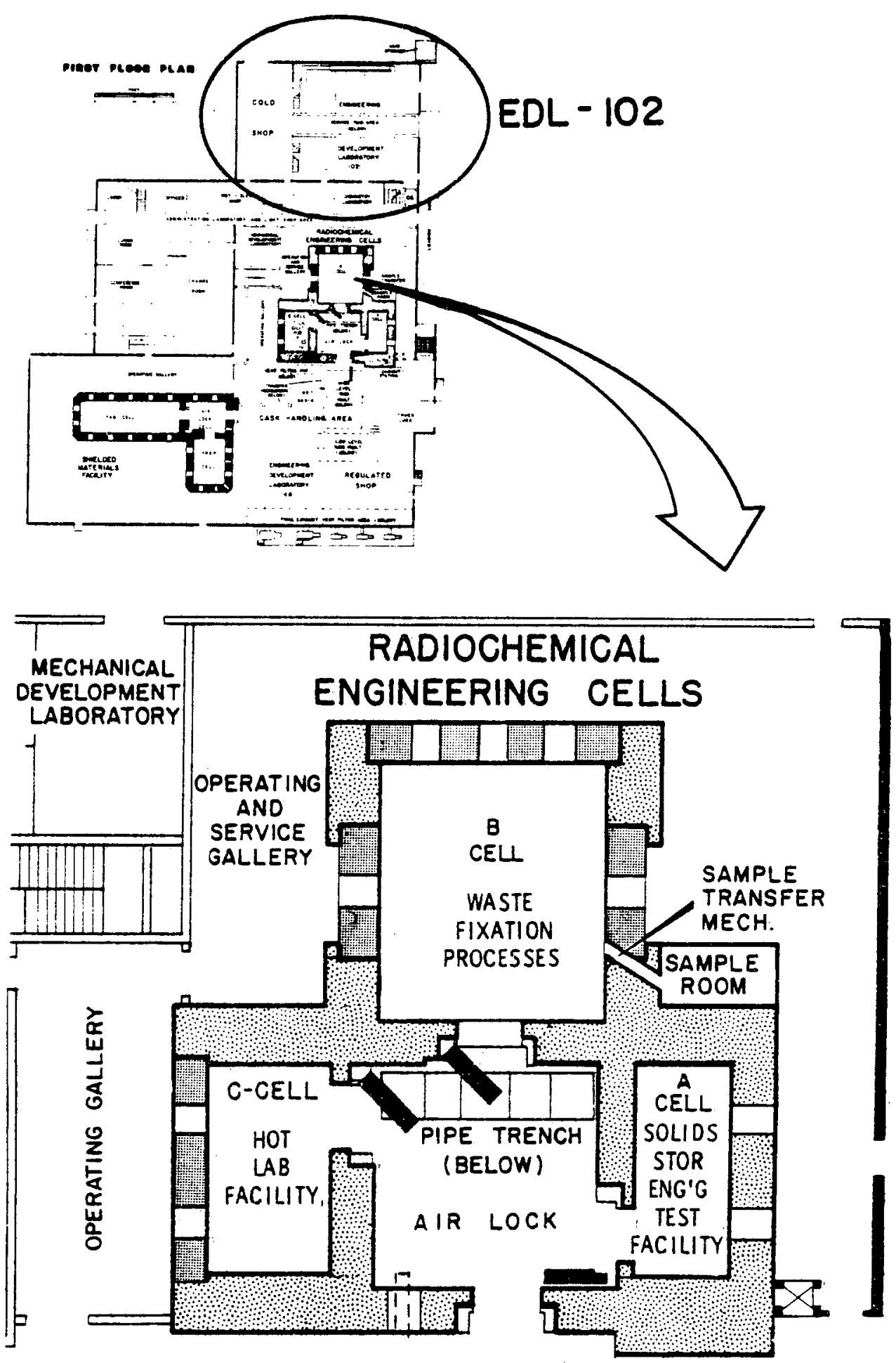

FIGURE 3. 324 Building Radiochemical Engineering Cells 


\subsection{Air Lock Cel1 Load-Out Port}

A shielded load-out port will be installed through the wall of the Air Lock Cell to the left of the doorway. Design of this load-out port will be similar in size, access and closure to those of the 325-A Building High-Level Cells. This port will provide a minimal exposure method of loading containers of chopped fuel into the Salt Cycle Waste Cask, (2) without moving the cask into the Air Lock Cell, for transfer to the Backup Fuel Dissolution System in 325-A Building. The port will also be used for returning leached hulls from 325-A to the 324 Building cell complex for use in the cladding hulls program and for loading out solids for cask transfer to the 200 Areas to TRU waste storage.

\subsection{Air Lock Cell Wal1-Mounted Jib Hoist}

Irradiated fuel assemblies will be received at the 324 Building Cask Handling Area in highway transport casks. The cask containing the spent fuel will be transferred into the Air Lock Cel1, opened, and the fuel removed and transferred to B-Cell. Because the existing Air Lock bridge crane has insufficient vertical clearance, a wall-mounted jib hoist will be used to remove the fuel assemblies from the casks and to place them in fuel thimbles. An interlock will be provided to prevent interference between the lifting devices.

\subsection{Cask Handling Area Facilites}

To facilitate the receipt, handling and release of the spent fuel transport casks at the 324 Building, the following modifications will be provided:

- The stop on the in-building railroad track will be moved and the travel of the 30-ton bridge crane increased to position the cask transporter under the crane in the Truck Lock.

- The existing 17-ton track used for moving the cask from the Cask Handling Area into the Air Lock Cell will be upgraded to 30-ton capacity. 


\subsection{Secondary Containment for Piping}

To prevent leakage of a radioactive solution from the process systems as a result of a piping failure, secondary containment will be provided for piping which conducts significantly radioactive process solutions. Highly radioactive solutions to be transferred within the 324 Building will be routed through piping installed within a stainless steel secondary containment sleeve which drains to the stainless-steel lined High-Level Vault. Other solution transfers will be made through the following routes: i) piping

- contained in stainless steel trays, 2) piping installed in cell floors, and

3) piping installed in a concrete envelope.

To provide for secondary containment of the latter two systems, stainless steel trays will be placed below the cells with in-floor piping and the concrete envelope. Capability will be provided to detect and remove any leakage which might occur. In addition, a concrete floor will be placed under A-Ce11, C-Cell and the Air Lock Cell.

\subsection{4-325 Interbuilding Pipeline}

A multiwall interbuilding pipeline (indicated on Figure 4 ) is to be installed as an integral part of the CNWVP. A major straight length ( $650 \mathrm{ft}$ ) of 2-in. schedule 40 , welded stainless steel pipe, surrounded by a 4-in. Fiberglas-reinforced epoxy encasement pipe, is in place between the buildings. The 2-in. pipe will be connected at both ends to piping in the 324 and 325 Buildings; it will serve as a secondary containment pipe for enclosed process solution transfer pipes. Two schedule 40 , 304-L stainless steel pipes, 3/8-in. and 3/4-in. diameter, will be installed inside the 2-in.-diameter pipe and appropriately connected at each end to permit transfers by suction of the dissolver solution and HLLW, respectively. Offgas from the 325-A Building process vessel vent system will be drawn through the annular space in the 2-in.-diameter pipe, monitored continuously, and discharged to the 324 Building stack. Specific additional criteria for this pipeline are as follows: 


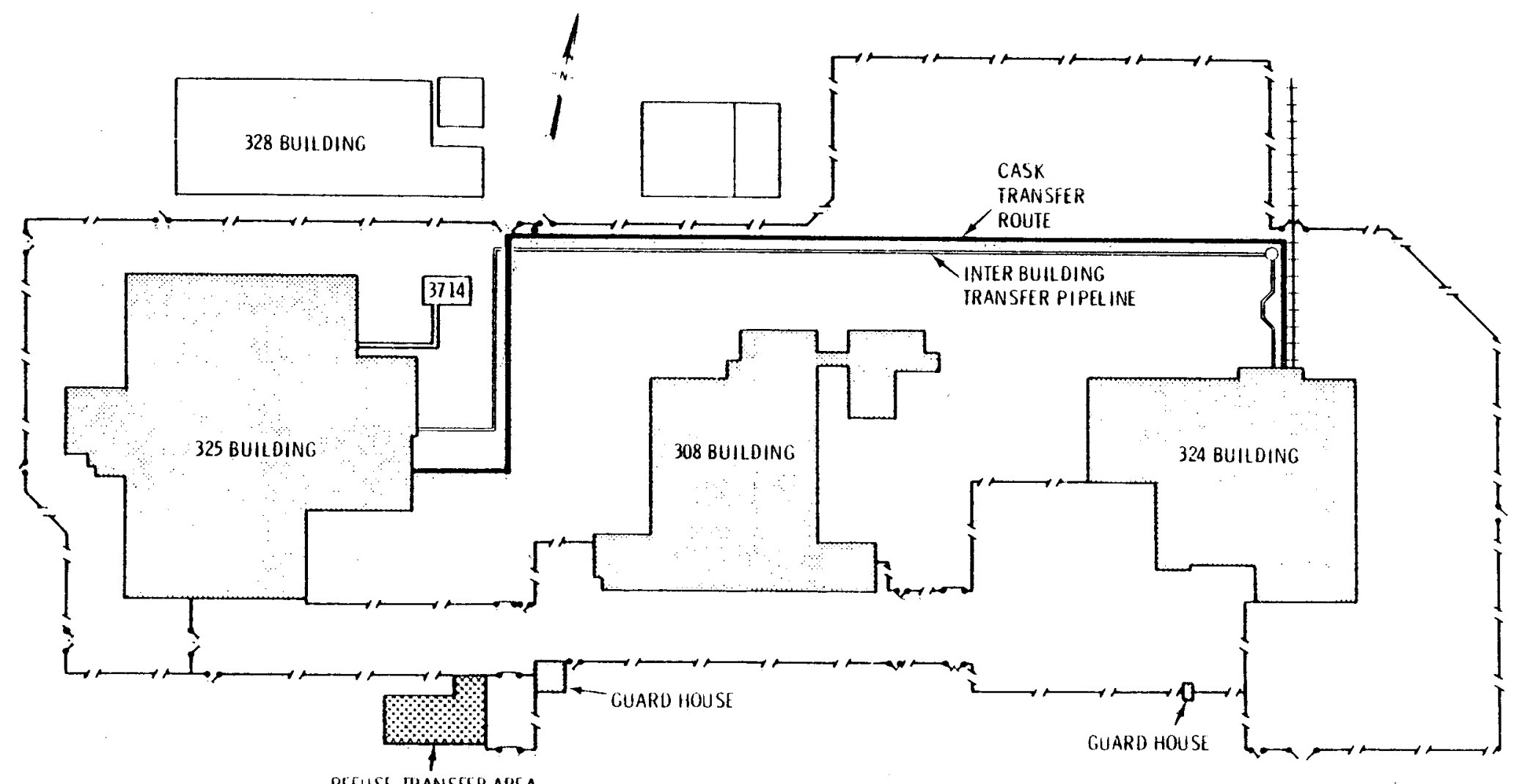

RIFUSE TRANSFER AREA

FIGURE 4. Plot Plan for 300 Area Protected Area 
- Leak test capability will be provided for both primary and secondary containments.

- All welds on lines carrying liquids will be checked by $100 \%$ NDE.

- Stainless steel process lines will be hydrostaticly tested at 100 psig.

- Cathodic protection will be provided.

- The lines will be designed for Uniform Building Code Zone II Earthquake conditions.

- Radiological shielding of the pipeline will be provided as required to assure no excessive exposure to personnel.

- Appropriate ground surface markings will be provided to prevent inadvertent excavation of the line.

Although the probability of rupturing the interbuilding pipeline is very low, caused either by mechanical excavation equipment or by a very severe earthquake, a study was made to model the pathway of a high-level waste leak to the soil and transport to the river. The study concluded that:

- it would require a leak of about 400 gallons to penetrate to ground water,

- liquids and radionuclides with an ion exchange coefficient of 0 would reach groundwater in about 90 days, and

- an additional 110 days would be required for groundwater transport of radionuclides to the river.

The plutonium, neptunium, ruthenium, cesium, uranium, strontium, palladium, the rare earths, and transuranics would be completely absorbed by ion-exchange with the soil. Isotopes that could reach the river include tritium, tellurium, technetium, and antimony.

Since transfers of liquids between the two buildings will be made by suction onty a small volume of liquid would be leaked to the soil if the line were ruptured while a transfer was in progress. The quantity would be a few gallons, essentially the holdup of the line from the supply tank to the point of the break. 


\subsection{Building - 300 Area Waste System Modifications}

\subsubsection{Uncontaminated Process Sewer Diverter System}

The existing 324 Building waste water diversion system, which diverts to a 20,000 gal underground retention tank, does not meet current ERDA-RL waste management program criteria because it does not provide secondary containment. Consequently, it will be abandoned and the system redesigned.

Four new monitoring and diverting systems will be installed inside the 324 Building to handle normally uncontaminated waste water flows to the 300 Area Process Sewer. Waste water from B-Cell equipment containing large inventories of highly radioactive materials will be segregated for flow through one diverter system. Waste water from three other groupings of equipment wi 11 be segregated for flow through the three other diverter systems. Each system will have the capability of automatically redirecting a stream from the normally uncontaminated process sewer to the appropriate storage tank in the 324 Building vault if radioactivity above a preset 7 imit is detected. These tanks all have secondary containment.

Upon detection of an abnormal contamination level in a stream it would be diverted to an in-building storage tank, and upon verification the process would be shut down--and the cause of the contamination corrected. Subsequently, the waste would be concentrated in the 324 Building evaporator system or removed by jet transfer to the 340 Facility (see 5.8.2) or by cask transfer (2) to interim storage, whichever is appropriate, before operations would be resumed. In addition to meeting the criteria for secondary containment, these new systems will practically eliminate the possibility of any significant release of radioactivity to the 340 Facility.

Connecting these new diverter systems to the in-building storage tanks may require decontamination of vaults and will require some in-building piping modifications. Other specific minor modifications (e.g., replacement of a water seal with a nonvolatile liquid seal for a filter system) will be made in the 324 Building to meet the waste management design criteria. 


\subsubsection{Radioactive Liquid Waste Sewer System}

The 300 Area intermediate level radioactive liquid waste lines (Crib Waste Sewer) serving the 308, 309, 324, 325, 326, 327 and 329 Buildings have, for the most part, been in service for over 20 years. The lines are direct-buried, single-wall stainless steel. Any leaks that might develop would release radioactive contamination to the ground. This system does not meet current waste management design criteria. Consequently, the entire existing radioactive contaminated sewer system will be replaced and upgraded by HEDL by early 1978.

The new radioactive liquid waste sewer system will have Schedule 40 , 304-L stainless steel pipe mains and laterals, valve pits, and cleanout pits, and will include Fiberglas-reinforced epoxy pipe encasement for double containment. Instrumentation to be provided will include radioactivity monitoring, flow metering, and leak detection. The new system will collect intermediate level radioactive liquid wastes from the 300 Area laboratory buildings listed above for transfer to the 340 Building load-out facility. There the liquid is discharged into catch tanks, chemically treated as appropriate, and loaded into tank cars for transport to the 200 Areas for processing and storage.

\subsubsection{Gaseous Effluent and Area Radiation Monitoring Systems}

The anticipated radioactive gaseous effluents from routine operations of the CNWVP are identified and evaluated in the Environmental Assessment report. (3) A11 process and vessel vent gaseous effluents from both 324 and 325-A Buildings will be released from the 50-meter 324 Building exhaust stack. Process and vessel vent systems and the building exhaust system are described in the Safety Analysis Report. (1)

In addition to existing $\beta / \gamma$ and $\alpha$ monitoring capability, equipment for continuously monitoring ${ }^{3} \mathrm{H},{ }^{85} \mathrm{Kr}$ and ${ }^{129} \mathrm{I}$ wi1l be added to the 324 Building stack monitoring system. The system will be operated and maintained by HEDL personnel to verify compliance with estabi ished release limits. A complete new system of fixed area radiation monitors (RAMs) will be installed 
in 324 Building. These systems will be supplemented by portable RAMs, portable $\beta / \gamma$ and a continuous air monitors, and by hand and shoe counters, to provide complete radiation protection surveillance for all operating personnel.

\subsection{Site Protected Area}

The presence of special nuclear materials (uranium and plutonium) in the fuel assemblies to be processed in the CNWVP necessitates additional safeguards measures beyond previous security requirements for the 324 Building. The irradiated fuel used in the process will be received, stored, chopped and dissolved in the 324 Building. The SNM control and accountability for these operations will be on an item-control basis. A record system showing the receipt, location and disposition of each fuel assembly will be maintained on a current basis. No measurements are required either of the fuel input to the dissolver or of the dissolved fuel. (The dissolved fuel wi11 be measured in the 325-A Building.) A11 operations in the 324 Building and the 325-A Building will be encompassed in a single material balance area.

HEDL will enclose the 324,308 and 325 Buildings within a "protected area" within the 300 Area, as shown in Figure 4. Physical security fencing, guard houses and related features will be provided. The above measures will limit vehicular and personnel traffic in the protected area to a minimum. 


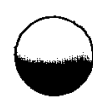

1

1

1

1

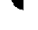

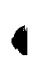




\subsection{EQUIPMENT DESCRIPTION}

\subsection{Existing Equipment}

The waste fixation equipment located in B-Cell, 324 Building was developed and operated under radioactive conditions during the WSEP Program in 1966-1970. (4) Major items of equipment needed for the CNWVP hot cell runs (e.g., spray calciner, melter furnace and offgas systems) were proven previously. Therefore, fabrication of completely new equipment is not required for initial operation of the cell. Most of this equipment is still prototypical of current designs and is described adequately in the Building SAR.

\subsection{Supplemental Equipment}

With the addition of the commercial fuel waste preparation task, it was decided to locate the fuel handling and chopping operation and the fuel dissolution and clarification operation in B-Cell.

\subsubsection{Fuel Handling and Chopping}

New equipment required for the fuel handling and chopping operation are: a) wall-mounted jib hoist, for higher vertical lift of fuel from cask than possible with the existing overhead bridge crane; b) fuel transfer thimbles and storage racks for assemblies awaiting chopping; c) disassembly tray and saws and cutters for removal of fuel assembly hardware; d) commercial shearing mechanism, equipped with an automatic hitch feeder that will pul1 fuel rods from the assembly for chopping fuel; and e) a hood-type structure to cover the shearing fixtures and direct fuel dust and gaseous effluents to the dissolver offgas cleanup system.

\subsubsection{Fuel Dissolution and Clarification}

The fuel dissolution system will have a dissolver in 324 Building B-Ce11 located beneath the chopped fuel chute. A removable perforated basket in the dissolver will contain the chopped fuel during dissolution and will be used for transfer of the cladding hulls after the dissolution step. The dissolver will hold a batch of $\mathrm{UO}_{2}$ containing $100 \mathrm{~kg}$ uranium, and will have an operating volume of 240 liters. The dissolver will be criticality safe 
by geometry and will employ recirculation to aid in dissolution efficiency. The dissolver system, diagrammed in Figure 5, will consist of the dissolver vessel, hul1 rinse tanks, chemical addition system, dissolver condenser, dissolver solution holding tank, air lift headpot, and offgas treatment system.

\subsection{Equipment Modifications}

\subsubsection{Frit Feeder System}

As a result of continuing equipment development, a frit feeder system has been designed that will allow for gravity flow of glass frit from a proportional feeder in the service gallery to the lower cone of the spray calciner in B-Ce11. All mechanical items of this system will be located outside the cell. An air lock will be provided in the frit addition line to restrict leakage of air into the calciner and to ensure against backflow from the calciner to the service gallery. The air lock and associated screened air vent will be located in a hood which will vent back to the cell through an absolute filter. A weigh belt feeder, located in the aqueous makeup room, will meter the glass frit addition.

\subsubsection{Quench Scrubber and Vacuum Boost System}

The quench scrubber will be a packed tower designed to simultaneously cool, condense and scrub the calciner offgas. The scrub tower will be a 10-in. Schedule $20304-L$ stainless steel vessel packed with 5/8-in. 304-L stainless steel Pall rings. Two liquid distributor weirs, one above the packing and one midway down the tower, will feed the scrub and quench liquids to the packing. A tank at the bottom of the tower will collect scrub and condensate liquids for feeding to a recycle pump. An overfiow from the tank will maintain the liquid level. A heat exchanger cooled with water will be used to cool the recycle stream. In normal operation, the recycle stream will be fed to the lower weir to quench the incoming gas while a cleaner stream such as fractionator distiliate will be fed to the upper weir to scrub. Capability to feed recycle to the upper weir and other streams to the lower weir will also exist. 

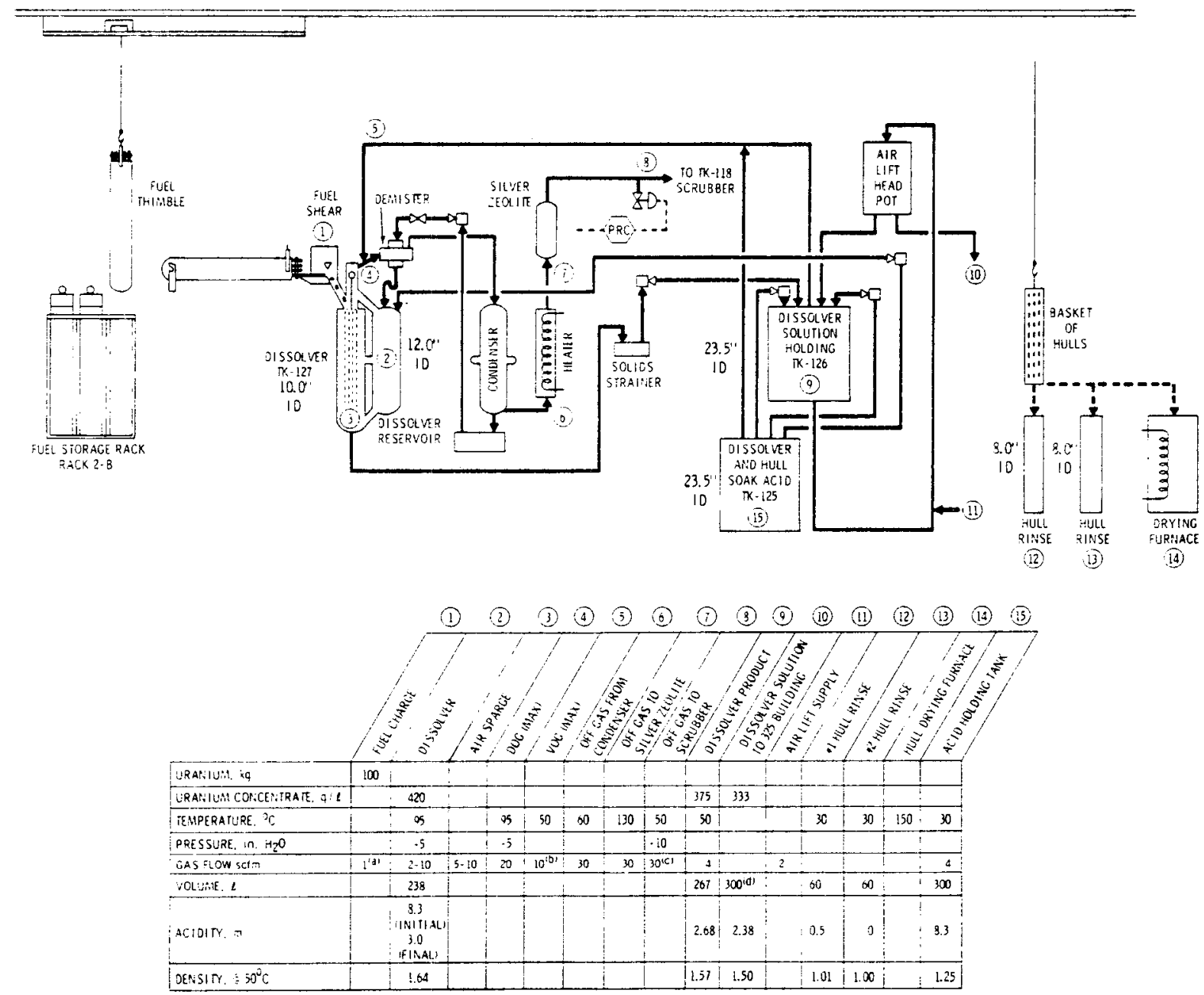

IaI INLEAKAGE OURING SHEARING

Ibi INCLUDES VARIOUS SPARGES. AIRLIFT GAS ETC

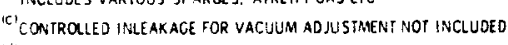

IdI INCLUDES $\sim 33.2$ TOTAL DHUUTION FROM FLUSHES

\section{FIGURE 5. Flowsheet and Material Balance 324 B-Cell Dissolver System}


A steam jet will be installed on the downstream side of the scrubber to assure a vacuum in the calciner during operation. Since the jet will add to the heat load on the system, a condenser will be installed to condense the steam. The condenser will be water-cooled.

\subsection{Equipment Instrumentation}

Instrumentation associated with CNWVP equipment and processes must fulfill information requirements in the areas of process operation and control, criticality safety, safeguards surveillance, radiological safety, scientific data records and management records. During the 1975 renovation of B-Cel1, a complete checkout and updating of all electrical, piping and instrumentation systems was accomplished. An equipment checkout run with acid feed was completed satisfactorily in January 1976, to verify operability of these systems.

\subsection{Development Modifications}

One objective of the waste fixation program is to keep equipment in tune with commercial fuel reprocessor's needs. Reviews of the functionality of equipment such as the offgas system are ongoing. Additions or modifications may be anticipated in order to update certain features of the CNWVP equipment, to improvements in technology, and, as necessary, to answer any questions in support of the design of a reprocessing plant waste management facility.

Development activities are under way to shake down the equipment and processes particularly in the following areas: a) fuel handling and chopping, b) a nondestructive assay instrument for measurement of the fuel remaining in the leached hulls, c) clarification of dissolver solution and handling of solids, d) glass frit addition to the spray calciner, e) determination of the operating characteristics of the quench scrubber system, and $f$ ) confirmation of the hydraulics of the 324-325 Interbuilding Pipeline.

A diagram of B-Cell equipment as planned for initial runs is shown in Figure 6 . 


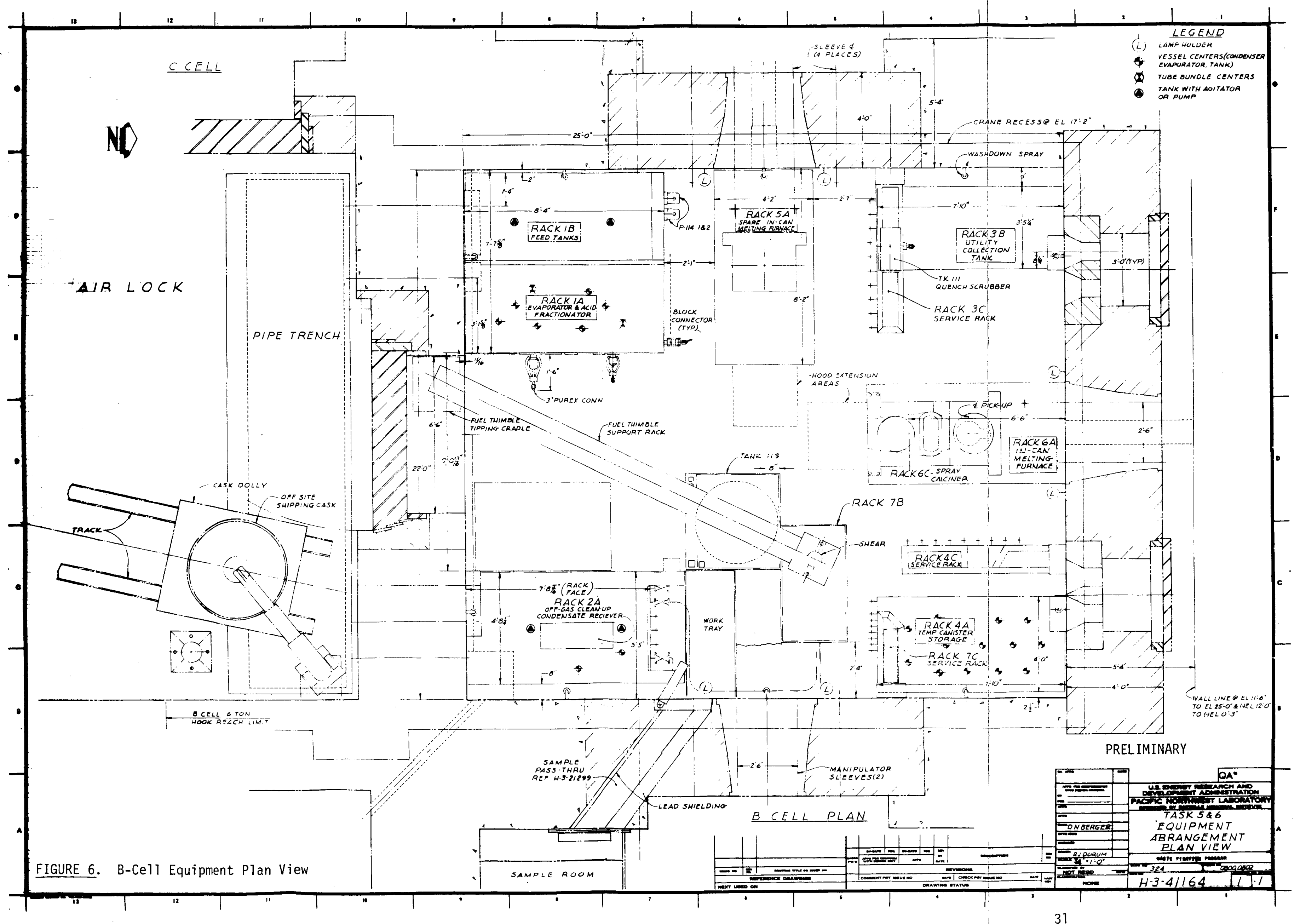




\subsection{ORGANIZATION AND ADMINISTRATIVE CONTROLS}

\subsection{Organization}

The ERDA has determined that conduct of its programs in 300 Area facilities requires that several of the buildings be shared between contractors. The 324 Building is one of the shared facilities. Management of this building has been assigned to HEDL, but certain space has been assigned to PNL (BNW) as a tenant. General relationships and responsibilities of the two contractors are established in a basic agreement, WHC/BNW Joint Occupancy Procedure; ${ }^{(6)}$ special detailed agreements for the 324 Building are included. A11 safety requirements and emergency plans are established by the HEDL Building Administrator, with PNL's approval. Although HEDL has the responsibility for keeping the building SAR up to date, an SAR Supplement covering changes in equipment or operations in PNL assigned space shall be prepared and processed by PNL with concurrent sign-off by the HEDL Building Administrator.

\subsection{Administrative Contro1s}

Most of the technical programs conducted in the Radiochemical Engineering Cells and the Engineering Development Laboratory are the responsibility of the Chemical Technology Department. The PNL Building Manager for the 324 Building, who provides liaison with the HEDL Building Administrator, is assigned to the Chemical Technology Department.

In addition to the safety requirements and emergency plans established by the HEDL Building Administrator, formalized controls for nuclear safety, radiological safety, and industrial safety are detailed in PNL Management Guides and procedures manuals. Operations with fissionable materials are performed under Criticality Safety Specifications which specify limits for safe handing and storage or, where limited quantities are used, under isolation control which precludes assembling a minimum critical mass within a facility. These Criticality Safety Specifications and controls are prepared by the component operating the facility and are reviewed and approved by the PNL Building Manager, the Manager, Safety and Nuclear Materials Management, the Manager, Nuclear Criticality, and the HEDL Building Administrator. 
Operations involving large quantities of by-product radionuclides are reviewed by the building manager and Safety and Nuclear Materials Management.

Operational Safety Requirements (OSR's) will be developed for approval by ERDA. The Nuclear Safety Limits estabiished by the Building SAR and this Supplement will be the basis for the OSR's. The OSR's will be prepared by the CNWV Project and reviewed and approved in accordance with the PNL internal nuclear safety review system for submittal to ERDA-RL for approval.

Safety and Nuclear Materials Maragement, an organization independent of the operating organization, makes periodic audits of conformance with the approved Criticality Safety Specifications and the Nuclear Safety Limits established by the building SAR and its supplements.

During the conduct of the CNWV Project the activities described in this Supplement are the responsibility of the Project organization described below. Responsibilities for other activities in the PNL portion of the 324 Building during the conduct of the Project are covered in the previously published SAR and remain the responsibility of the Chemical Technology Department. After the CNWV Project ends the Chemical Technology Department will be responsible for activities described in this Supplement as well as the other R\&D activities.

The CNWV Project organization is shown in Figure 7.

During the design and construction of the CNWVP, the Task Leader, Waste Vitrification Task is responsible for developing the conceptual design, providing the technology input to, and obtaining peer review of the detailed design to assure that process performance will be satisfactory. The Task Leader has the authority to approve design drawings for technical adequacy. The Manager, Demonstration is responsible for reviewing and approving the design for operability. A Design and Operations Review Committee reviews systems and selected equipment for industrial safety, criticality safety, radiological safety, safeguards/accountability, and operability; Committee approval is required for the systems and items reviewed. Design drawings, purchase requisitions, and work orders are reviewed and approved by the Quality Assurance Specialist. 


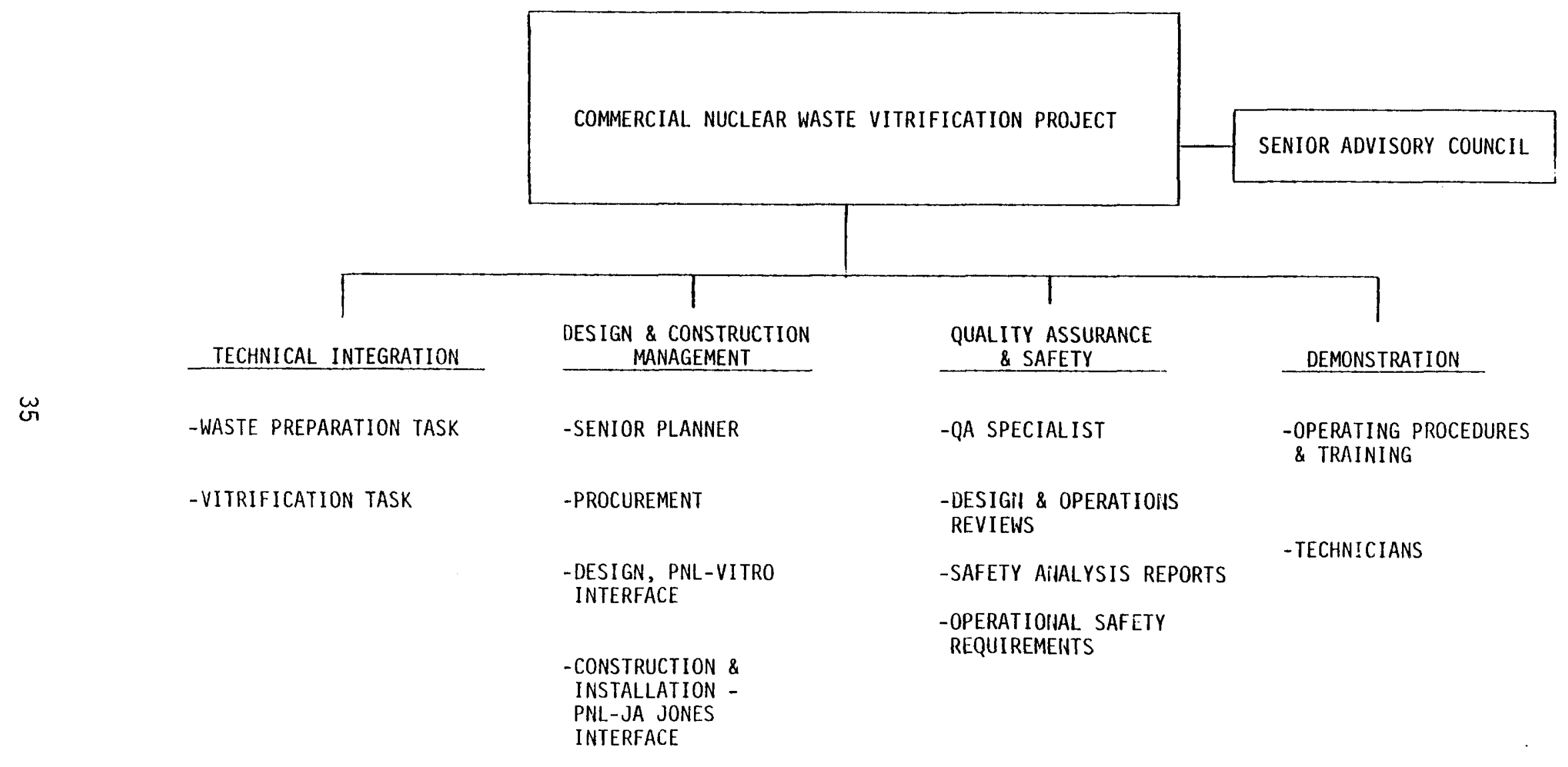

FIGURE 7. Commercial Nuclear Waste Vitrification Project Organization 
Primary technical responsibility, including Process Technology, for the CNWVP is assigned to the Manager, Technical Integration. He has the following safety responsibilities in connection with his Process Technology functions:

a. Prepare instructions for operational tests to demonstrate the capability to meet safety and process requirements,

b. Prepare Process Specifications

c. Prepare Criticality Safety Specifications

d. Prepare detailed run plans

e. Review the Safe Operating Procedures and Emergency Procedures and significant revisions,

f. Audit operations for compliance with Process Specifications and Criticality Safety Specifications,

g. Monitor the training program for technical adequacy.

The Manager, Technical Integration has the authority to recommend the shut down of operations if they are not in compliance with the Process Specifications or Criticality Safety Specifications.

Primary operating responsibility for the CNWVP is assigned to the Manager, Demonstration. His safety responsibilities are:

a. Approve or reject from a safety and operating standpoint all demonstration activities in this facility,

b. Approve Criticality Safety Specifications and Process Specifications,

c Approve detailed run plans,

d. Prepare and approve Safe Operating Procedures and Emergency Procedures,

e. Manage the treatment and disposal of wastes from the facility in conformance with established criteria,

f. Maintain inventory records on source, special nuclear, and by-product material entering, in, and leaving the facility,

g. Provide for the maintenance of the CNWVP equipment,

h. Maintain a well-trained staff which operates safely. 
The Manager, Demonstration has the authority to defer startup or to shutdown operations when in his judgement an unsafe condition exists.

Responsibility for the organization and preparation of safety documentation for the project is assigned to the Manger, Quality Assurance and Safety, who is also responsible for the organization and implementation of the CNWV Project QA PIan. His safety responsibilities are:

a. Prepare Safety Analys is Report Supplements,

b. Organize and conduct safety analyses in support of SAR Supplements,

c. Prepare Operations Safety Requirements,

d. Prepare Operational Readiness Report,

e. Review the design for safety,

f. Review the Process Specifications,

g. Review the Operating Procedures and Emergency Procedures.

The Manager, Quality Assurance and Safety has the authority to stop work to prevent the continuation of unsatisfactory work practices or the installation of nonconforming items.

Responsibility for overall project Design and Construction coordination and management in accordance with the technical and safety criteria and within schedule and cost constraints is assigned to the Manager, Design and Construction Management. His safety responsibility is to approve the design and construction for conformance with the design safety criteria. He has the authority to approve design, procurement and construction within design criteria restrictions. 


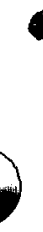

$\theta$ 


\subsection{SAFETY ANALYSIS}

\subsection{General}

The Commercial Nuclear Waste Vitrification Project will require the storing and processing of kilogram quantities of fissionable material in addition to the processing of megacurie quantities of fission products. A general discussion of the safety of waste solidification studies is given in the 324 Building SAR, BNWL-CC-2028; credible accidents in the waste vitrification task are also described. Storing and dissolving significant quantities of irradiated power reactor fuel elements presents some unreviewed safety questions, particularly the design features and controls used to preserve nuclear criticality safety.

\subsection{Control of Off-Standard Conditions}

Off-standard processing conditions will be detected in numerous ways. Process instrumentation (in-line analytical and process control) will usually provide the primary indications; process control instrumentation is designed to be fail safe. Administrative controls (e.g., fuel identity information, sign-offs on operating procedures for batch operations and observation-recording of key data by technicians) will provide the other primary indications. Laboratory analyses of samples will be a secondary measure. Examples of some possible off-standard conditions are shown in Table 2. Where corrective action is not indicated in the standard operating procedures, rework procedures or other special procedures will be provided by process technology or operations engineers, as appropriate, and reviewed and approved by the other. 
TABLE 2. Control of Off-Standard Conditions

\begin{tabular}{|c|c|c|c|c|}
\hline $\begin{array}{l}\text { Process } \\
\text { System }\end{array}$ & $\begin{array}{c}\text { Off-Standard } \\
\text { Condition }\end{array}$ & $\begin{array}{c}\text { Key } \\
\text { Instrumentation }\end{array}$ & $\begin{array}{l}\text { Administrative } \\
\text { Control }\end{array}$ & $\begin{array}{c}\text { Corrective } \\
\text { Action } \\
\end{array}$ \\
\hline \multirow[t]{2}{*}{$\begin{array}{l}\text { Fuel } \\
\text { Chopping }\end{array}$} & $\begin{array}{l}\text { Unleached fuel } \\
\text { removed from } \\
\text { dissolvers }\end{array}$ & $\begin{array}{l}\text { Leached hull } \\
\text { monitor }\end{array}$ & $\begin{array}{l}\text { Procedural } \\
\text { sign-off }\end{array}$ & Recycle \\
\hline & $\begin{array}{l}\text { Chopping fuel } \\
\text { into dissolver } \\
\text { containing hulls }\end{array}$ & Chute fills up & $\begin{array}{l}\text { Procedural } \\
\text { sign-off }\end{array}$ & $\begin{array}{l}\text { Manual } \\
\text { removal of } \\
\text { chopped fuel }\end{array}$ \\
\hline \multirow[t]{2}{*}{ Dissolving } & $\begin{array}{l}\text { Overconcen- } \\
\text { tration }\end{array}$ & Redundant sp. gr. & $\begin{array}{l}\text { Procedural } \\
\text { sign-off }\end{array}$ & Dilution \\
\hline & $\begin{array}{l}\text { Plugged sp. gr. } \\
\text { dip tube }\end{array}$ & $\begin{array}{l}\text { Redundant sp. gr. } \\
\text { comparison }\end{array}$ & $\begin{array}{l}\text { Procedural } \\
\text { sign-off }\end{array}$ & $\begin{array}{l}\text { Unplug and } \\
\text { repair }\end{array}$ \\
\hline
\end{tabular}

\subsection{Criticality Safety}

The potential for an accidental criticality event depends not only on the amount of. fissionable material present, but also on other factors such as density, geometry, materials admixed or interspersed with the fissionable material, concentration of solutions of fissionable material, and neutron reflection by the surrounding media. In the design of equipment and operational planning for processing fissionable material the two contingency policy is a basic criterion. (a) criticality safety is controlled by:

- mass control,

- geometry control, or

- concentration control

Fissionable material used in the CNWV Project wi 11 be irradiated nuclear power reactor fuel elements that had an initial enrichment of no more than $3.5 \% 235 \mathrm{U}$, and burnup of 15,000 to $30,000 \mathrm{MWd} /$ tonne. The initial enrichment of the fuel elements before irradiation and the equivalent ${ }^{235} U$ enrichment after exposure will be verified by the certified fabrication and exposure records furnished by the irradiated fuel supplier. The in-reactor behavior history of each fuel element, as indicated in the certified exposure record, will be reviewed for anomalies indicative of the enrichment of the fuel.

\footnotetext{
(a) Two contingency policy -- at least two unlikely, independent and concurrent events must occur before criticality is possible.
} 
Each fuel element is identified by a serial number stamped on the top end hardware of the fuel bundle. The serial numbers indicated on the shipping documents will be verified by inspection before the fuel is removed from the shipping cask in the Air Lock Cell. Further verification will be given by the accountability analyses. In 324 Building B-Cell up to nine irradiated fuel elements will be stored in thimbles held in a rack designed to be critically safe even if the cell were flooded with water. The irradiated fuel storage rack is designed to accomodate only one fuel storage thimble in each of the nine storage positions. Each thimble can accomodate only one fuel element bundle; therefore, it is not possible to double batch in any storage position. The fuel elements will be disassembled, the rods cut in short lengths, and dissolved in nitric acid. The concentration of the uranyl nitrate solution (UNH) in the dissolver at the end of the dissolving operation will be $420 \mathrm{~g} \mathrm{U} / \mathrm{l}$. In the dissolver solution holding tank the UNH solution will be diluted to a concentration of $375 \mathrm{~g} \mathrm{U} / \mathrm{l}$, which will have a crystallization temperature low enough to avoid crystallization problems during the transfer of the solution to the 325-A Building through the interbuilding pipeline. (a)

The criticality safety limits for UNH solution are greater than they would be for a $\mathrm{UO}_{2}$ slurry in water because of the nitrate ions present. There are only two ways by which nitrate ion could be absent, either by addition of water rather than nitric acid to the dissolver or by chemical elimination of the nitrate ion from the solution. If only water were added to the dissolver no reaction would take place and the uranium oxide would remain within the dissolver basket, which has been determined by criticality safety analysis to be a safe condition. Elimination of the nitrate ion from solution is impossible in the CNWVP equipment since elimination of nitrate ion to the extent required for separation of uranium oxide would necessitate calcination to $\mathrm{UO}_{3} \cdot \mathrm{UO}_{3}$ calcination occurs at temperatures of 250 to $300^{\circ} \mathrm{C}$. The 100 psig steam supplied to the 324 and $325-\mathrm{A}$ facilities will give a maximum temperature of only about $170^{\circ} \mathrm{C}$. Therefore, calcination to the oxide could not occur.

(a) If crystaliization were to take place inadvertently steam could be bled through the 3/4-in. line to heat the 3/8-in. Tine and dissolve the crystals. 
Accumulation in the system of small particles of $\mathrm{PuO}_{2}$ or $\mathrm{UO}_{2}$ which might pass through the dissolver solution clarification filter should not be of concern because:

(1) Published results of studies indicate that the solids remaining after a normal dissolution cycle amount to only a few tenths of a percent of the initial fuel weight, and that the bulk of this undissolved material is not $\mathrm{PuO}_{2}$ or $\mathrm{UO}_{2}$, but rather fission product alloys and/or oxides. ${ }^{7}$ Most of this solid material is reported to be easily slurried.

(2) Particles small enough to pass through the 100-micron filter would tend to remain in suspension in the air-sparged feed and waste tanks and thus transfer along with the solutions rather than accumulating. The particles would also tend to accompany the aqueous phase out the bottom of the HA column, with some accumulation at the bottom interface being likely.

(3) Any undissolved $\mathrm{UO}_{2}$ particles which do pass through the filter would tend to continue to dissolve in later process steps; the rate would likely be appreciable in any of the tanks having a temperature of $40^{\circ} \mathrm{C}$ or greater and should be quite rapid in the final waste concentrator.

A11 of the process vessels in 324 Building B-Cell are critically safe by geometry for UNH solution made from irradiated fuel exposed to 15,000 MWD/TU that had an initial enrichment of $3.5 \%{ }^{235} \mathrm{U}$. For UNH solutions made from fuel initially enriched to $3.5 \% 235 \mathrm{U}$ and irradiated to $15,000 \mathrm{MWD} / \mathrm{TU}$ the minimum critical dimensions are:

- Minimum critical volume - 950 e

- Minimum critical diameter - 35.4 in.

- Minimum critical slab-thickness - 21.5 in.

Full water reflection was assumed for these calculations to provide a degree of conservatism. 
The only places where leaking dissolver solution could collect are the catch tanks in which the dissolver and dissolver solution holding tank are located. The dissolver is located in a catch tank of $315 / 8-i n$. ID. If the dissolver solution were to leak into the catch tank the depth of the solution would be about 19-in. This is less than the minimum critical slab thickness of 21.5-in. for UNH solution made from irradiated fuel exposed to 15,000 MWD/TU. Similarly, the dissolver solution holding tank is located in a catch tank of 41.5-in. ID. If a batch of dissolver solution were to leak into the catch tank the depth of the solution would be about 11-in., much less than the minimum critical slab thickness. Since batch size in these vessels is limited to $100 \mathrm{~kg} \mathrm{U}$ which is less than $45 \%$ of the minimum critical mass of $3.5 \%$ enriched UNH solution, a spill of the contents of either vessel into its catch tank would be subcritical even for unirradiated UNH solution.

Even for UNH solution made from unirradiated $3.5 \%$ enriched uranium there are only two tanks in the 324 Building B-Cell that are slightly larger than the minimum critical diameter for this solution. The criticality safety parameters for UNH solution made from unirradiated $3.5 \%$ enriched UNH are given in Table 3.

TABLE 3. UNH Criticality Safety Parameters $3.5 \% 235 \mathrm{U}$ Enrichment, Full $\mathrm{H}_{2} \mathrm{O}$
Reflection

\begin{tabular}{|c|c|c|}
\hline inimum & critical mass & 240 \\
\hline Minimum & critical concentration. & $505 \mathrm{~g} \mathrm{U} / 2$ \\
\hline Minimum & critical solution volume & 250 \\
\hline Minimum & critical diameter. & 22.2 \\
\hline Minimum & critical slab thickness. & \\
\hline When $k_{\infty}$ & $=0.95$ the UNH concentration & $U / \ell$ \\
\hline When $k_{e f}$ & $\begin{aligned} \mathrm{ff}= & 0.95 \text { the UNH concentration } \\
& \text { and the cylinder diameter }\end{aligned}$ & $=1025$ \\
\hline
\end{tabular}

When $\mathrm{UO}_{2}$ is dissolved in $8.3 \mathrm{M} \mathrm{HNO}_{3}$ with an excess of $\mathrm{UO}_{2}$ present the maximum UNH concentration without boiling off water will be. . . . . . . . . . $680 \mathrm{~g} \mathrm{U} / \mathrm{l}$ 
The dissolver is designed to be critically safe by geometry. However, the two tanks that receive solution from the dissolver are $23.5 \mathrm{in}$. ID, slightly greater than the minimum critical diameter of 22.2 in. for unirradiated $3.5 \%$ enriched UNH but less than the minimum critical diameter for UNH from fuel irradiated to 15,000 MWd/TU. They are the dissolver solution holding tank and the dissolver and hull soak acid tank.

Dissolver Solution Holding Tank and Dissolver and Hull Soak Acid Tank

Hazard - The tank diameter is 1.3 inch greater than the minimum critical diameter for UNH solution enriched to $3.5 \%{ }^{235} \mathrm{U}$.

Safety Parameters (for $3.5 \% 235 \mathrm{U}$ as UNH)

1. Minimum critical mass of UNH solution is $240 \mathrm{~kg} \mathrm{U}$.

2. Minimum critical volume of UNH solution is $250 \&$ at a concentration of $1100 \mathrm{~g} \mathrm{U} / \mathrm{l}$.

3. Minimum critical concentration of UNH solution is $505 \mathrm{~g} \mathrm{U} / \mathrm{l}$.

4. The critical concentration of UNH solution in a tank of this diameter is $870 \mathrm{~g} \mathrm{U} / \mathrm{l}$.

\section{Safety Controls}

1. The dissolver batch is limited to $100 \mathrm{~kg} \mathrm{U}$ by procedure and to $155 \mathrm{~kg} \mathrm{U}$ by capacity of the basket and chute in the dissolver.

2. The dissolver solution concentration is controlled to $420 \mathrm{~g} \mathrm{U} / \mathrm{l}$.

3. The dissolver sollition batch volume is 240 l.

4. The dissolver solution holding tank has a volume of $300 \ell, 25 \%$ greater than a dissolver batch of $240 \ell$.

5. The dissolver is equipped with a reflux condenser to prevent concentration of the dissolver solution by boiling off water.

\section{Contingencies}

1. More than $240 \mathrm{~kg} \mathrm{U}$ instead of $100 \mathrm{~kg}$ would have to be charged to the dissolver and dissolved in 240 \& of solution. Only 
slightly more than $100 \mathrm{~kg} U$ as chopped fuel can be charged to the dissolver at one time because of the limited size of the fuel basket in the dissolver. Even if this $\mathrm{UO}_{2}$ could be dissolved in 240 \& of solution the concentration would be $1000 \mathrm{~g} \mathrm{U} / \mathrm{l}$ which is less than the UNH concentration of $1050 \mathrm{~g} \mathrm{U} / \mathrm{l}$ for criticality at the minimum critical diameter of 22.2 inch.

2. Either the specific gravity instruments (redundant instruments) would have to fail or be ignored for the technician to allow the concentration to reach $>1050 \mathrm{~g} \mathrm{U} / \mathrm{l}$. $(420 \mathrm{~g} \mathrm{U} / \mathrm{l} \simeq$ density $1.5 \mathrm{~g} / \mathrm{ml}$ at boiling point; $1050 \mathrm{~g} \mathrm{U} / \mathrm{l} \simeq$ density $2.3 \mathrm{~g} / \mathrm{ml}$.)

3. To reach a concentration of greater than $1000 \mathrm{~g} \mathrm{U} / \mathrm{l}$ the cooling water to the reflux condenser would have to be turned off so that the solution would concentrate.

4. The tank would have to be fully reflected with water.

\subsection{Routine Environmental Releases}

An environmental assessment of the conduct of the Commercial Nuclear waste Vitrification Project was published in February $1977 .(3)$ The assessment was based upon the following expected conditions:

a) The fuel will have a maximum content of radioactive material as shown in the ORIGEN data for 30,000 MWd/tonne irradiation followed by storage for at least one year after discharge.

b) The throughput will average one tonne per month.

c) Those process streams containing tritium will be controlled to restrict tritiated water release in the gaseous effluent system.

d) The dissolver offgas containing ${ }^{85} \mathrm{Kr}$ will be released via the 324 Building stack.

e) Final filtration of gaseous effluents will include a minimum of two-stage HEPA filtration and a charcoal filter in the 324 Building.

Estimated environmental doses from routine CNWVP operations calculated by the methods discussed in Appendix III of ERDA-1538, (8) are summarized in Table 4. 
TABLE 4. Estimated Environmental Doses

First Year Dose

Maximum Population Individual Dose

Rem

Person-Rem

\begin{tabular}{cc}
50 Year Dose Commitment \\
\hline Maximum & Population \\
Individual & $\begin{array}{c}\text { Dose } \\
\text { Rem }\end{array}$ \\
\hline
\end{tabular}

$1.3 E-5 \quad 1.1 E-1$

Externa 1

Whole Body $1.3 \mathrm{E}-5^{(\mathrm{a})} 1.1 \mathrm{E}-1 \quad 1.3 \mathrm{E}-5 \quad 1.1 \mathrm{E}-1$

Inhalation

$\begin{array}{llllll}\text { Whole Body } & 1.7 \mathrm{E}-8 & 2.8 \mathrm{E}-5 & 3.2 \mathrm{E}-8 & 5.2 \mathrm{E}-5 \\ \text { Lungs } & 5.6 \mathrm{E}-7 & 9.2 \mathrm{E}-4 & 1.2 \mathrm{E}-6 & 2.0 \mathrm{E}-3 \\ \text { Bone } & 1.4 \mathrm{E}-8 & 2.3 \mathrm{E}-5 & 4.1 \mathrm{E}-8 & 6.7 \mathrm{E}-5 \\ \text { Thyroid } & 1.2 \mathrm{E}-5 & 2.0 \mathrm{E}-2 & 2.2 \mathrm{E}-5 & 3.6 \mathrm{E}-2\end{array}$

Tritium

Whole Body 1.4 E-5 $2.3 \mathrm{E}-2 \quad 1.5 \mathrm{E}-5 \quad 2.5 \mathrm{E}-2$

(a) Computer format for exponential functions. E-5 is equivalent to $10^{-5}$.

From the results listed in Tabie 4, estimated annual environmental dose to the maximum exposed individual is calculated to be $0.03 \mathrm{mrem}$ (whole body). The contributions from external radiation (primarily from ${ }^{85} \mathrm{Kr}$ ) and from inhalation of tritiated water vapor are about equal. The cumulative population dose to those residing within 50 miles is about 0.1 person-rem (whole body). The additional annual dose to the thyroid from iodine inhalation is about 0.01 mrem for the maximum exposed individual and 0.02 personrem (thyroid) for the population. For the thyroid exposures, estimates of the 50-year dose commitments are about twice the annual dose.

The calculated environmental doses expected from the Commercial Nuclear Waste Preparation Task are compared in Table 5 with those resulting from past waste management activities conducted at Hanford, $(8,9,10)$ and with dose criteria for environmental levels proposed by the U.S. Environmental Protection Agency. (11) The environmental doses anticipated from the proposed waste preparation task are well below those shown for waste management 
activities conducted at Hanford in 1972, and are comparable with the doses experienced during the past two years. The calculated total body dose to the maximum exposed individual is higher for the proposed task but this merely reflects the shorter distance between the location of the hypothetical maximum exposed individual and the 300 Area versus the 200 or $100-\mathrm{N}$ Areas. In all cases, the calculated doses are far below applicable ERDA standards, ERDA Manual Chapter 0524, and standards proposed by the EPA for nuclear power operations.

\section{TABLE 5. Comparison of Calculated Doses From the Waste Preparation Task With Those From Past Hanford Operations and With Proposed EPA Criteria}

Annual Dose

From Waste From Hanford

Preparation Operations

Type of Exposure Task 1972(a) 1974-1975(b)

Individual, (c) Total Body (mrem)

0.03

0.6

0.02

$25^{(d)}$

Individual, ${ }^{(c)}$ Thyroid (mrem)

0.04

1.4

0.7

$75^{(d)}$

Population, Total Body (person-rem)

0.1

2.5

Population, Thyroid (person-rem)

0.1

12

3

(a) Final Environmental Statement, Waste Management Operations. (8)

(b) Average based on values reported for 1974 and $1975 .(9,10)$

(c) Calculated for the maximum exposed individual.

(d) Limits are proposed for the average individual only.

\subsubsection{Tritium Recovery and Control}

That portion of the tritium which is scrubbed out of the process offgas will be transported in shielded trucks or railroad tank cars and added to the 200 Area waste management operations. The amount will be about $90 \%$ of the total tritium received in the irradiated fuel or about 425 curies 
per month. Over the anticipated five-year life of the waste preparation operation, this addition (25,000 curies) will represent an insignificant $0.1 \%$ of the current Hanford inventory (3.5 $\times 10^{7}$ curies) - see page II.1-68 of ERDA-1538. (8)

\section{$8.4 .2{ }^{85} \mathrm{Kr}$ Releases}

The most abundant radionuclide in the gaseous effluent from the 324 Building will be ${ }^{85} \mathrm{Kr}$ in the dissolver offgas. The release rate will be about $10,000 \mathrm{Ci} /$ month. ${ }^{(3)}$ The estimated annual average ${ }^{85} \mathrm{Kr}$ concentration at the site boundary will be no greater than the 0524 Appendix, Table II value for ${ }^{85} \mathrm{Kr}$.

\subsection{Cask Shipment}

Radioactive shipping casks will be used to transport radioactive materials generated during the CNWV; this will include both liquids and solids. Six casks are available for transport of radioactive materials within the confines of the Hanford Reservation. Although these casks do not meet all of the requirements established by the DOT, administrative controls approved by the Energy Research and Development Administration's Richland Operations Office will be applied to assure compliance with the safety requirements of ERDA-RL Manual Chapter 0529. Safety analyses for each of these casks have shown them to be adequately safe for use on the Hanford Reservation. (2)

\subsection{Hypothetical Accidents}

A comprehensive accident analys is review was performed covering the accidents which could be postulated in the waste preparation phase of the CNWVP. (12). The spectrum of accidents encompassed operations in both the 324 and 325-A Buildings. Accidents were selected for analysis by a careful review of the function, description, and design of the project. The postulated accidents, when considering environmental effects, were classified as 1) minor, 2) moderate, and 3) maximum credible. Potential accidents considered were:

1) Minor

- Loss of services

- Loss of contamination control

- Equipment failure 
2) Moderate

- Small solvent fire

- Small in-cell trash fire

- Ventilation system failure

- Fuel-cask accident

- Transportation accident

- Pipe/tank leak

3) Maximum Credible

- Design basis fire

- Design basis explosion

- Design basis criticality

- Design basis flood

- Design basis earthquake

- Windstorm

For each accident in the last two categories, relevant aspects of the following topics were considered:

- possible causes and accident chronology,

- material involved,

- nature and amount of effluent released to the environment,

- probability of occurrence,

- engineered safety features provided,

- violations or failures necessary for accident occurrence, and

- radiological consequences of accident.

Two approaches were used to assess source terms for the postulated accident. All of the accidents except an accidental criticality deal with the dispersal of fuel or fission products contained in various stages of the chemical separations process. An accidental criticality would deal with the dispersal of volatile fission products.

For accidents concerning dispersal of fuel or fission products, an "inventory--release--fraction--source term" approach was taken. In the analysis of each accident, the radionuclide inventory present at the site of 
the incident was determined. The chemical and physical form of each inventory contributed to calculation of the fractional airborne releases. Other elements affecting the final release fraction included: dispersal mechanisms (fire, explosion, air movement, etc); plate-out on solid surfaces; air velocity and direction; and filtration of the inventory prior to reaching the environment. Multiplication of the derived inventory by calculated or experimentaliy determined release fractions yielded the source term released to the environment.

The postulated criticality event assumed multiple excursions involving $4 \times 10^{19}$ fissions over a $24-h r$ interval. (The probability that a criticality of this magnitude would occur is very low but not zero). A program for fission product buildup and decay was used to compute the quantities of noble gases and iodines resulting from $10^{18}$ fissions occurring over a $1 / 2$ second interval. The results of this calculation were then scaled to yield the quantities of noble gases and iodines released to the atmosphere from the event for each time period considered. The quantities released during the first 8 hours were assumed to be $25 \%$ of the iodines and 100\% of the noble gases present at 15 minutes after each burst. For the balance of the day, the assumed releases were $25 \%$ of the maximum iodines formed and $100 \%$ of the maximum noble gases formed, regardless of the decay time at which these concentrations were reached. Source terms for the population doses were derived by summing the quantities released for all time intervals. In all cases, the radionuclide activities were corrected for decay during the time of transit to the point of interest using a $1 \mathrm{~m} / \mathrm{s}$ wind speed.

In the calculation of consequences and occurrence probabilities, parameters were selected that would result in conservative "worst case" analysis. These assumptions include the following:

- All particles reaching the environment are of respirable size.

- The solubility states used in the tables for radionuclides reaching each critical organ are the most restrictive possible from a dose standpoint.

- The offsite individual at maximum radiological risk is located 2000 meters from the plant.

- High efficiency particulate air (HEPA) filters are $99.95 \%$ efficient for each stage. 
When doses for accident cases were calculated, the individual at maximum radiological risk was assumed to be exposed to the release for the duration of the accident. For calculation of population doses, the meteorology and population distribution of the region were used.

Most occurrence probabilities in the accident analyses were developed on a frequency-of-occurrence basis for two reasons: 1) because data on industrial accident occurrence already exist and usually have the normalized form, and 2) because data normalized over time permit estimation of annual risk by simply summing frequency-based values to yield the total postulated environmental impact from accidents.

The analyses of only those accidents pertinent to the operations conducted in the 324 Building and having the greater environmental consequences are presented in this Safety Analysis Report Supplement.

\subsubsection{Ventilation System Failure}

The ventilation and HEPA filter system are the basis for maintaining control of airborne radioactivity. Loss of integrity of this system may lead to an airborne release of radionuclides within the 324 Building or to the environment. Since all potentially contaminated ventilation exhausts must pass through a minimum of two HEPA filter stages and one charcoal adsorber stage before release to the environment, failure of any one filter would not be expected to cause a signficant release of radioactive materials.

The postulated ventilation system failure accident involves the complete loss of building ventilation and is based on extremely conservative assumptions. Even if no remedial actions were instituted, the consequences described below represent a "worst case" for this type accident. In a real accident, a number of factors would tend to mitigate the consequences. One factor is the stack effect in the 324 Building, which tends to maintain ventilation flow. Also relevant is the fact that the hot cells are relatively airtight except for ventilation iniets and exhausts. Consequently, any loss of forced ventilation would tend to leave the cell environment in a static condition so that any diffusion out of the cells and into work areas would be very slow. In addition, if ventilation failure is based on complete 
loss of electrical power to the facility, a portable generator may be brought in and connected to building emergency power busses. Previous experience at Hanford 300 Area facilities indicates that this emergency electrical hookup could be accomplished within $1 / 2$ to 2 hours of a complete building electrical outage.

A ventilation system failure involving the loss of negative pressure within the cells relative to the surrounding room might allow some airborne radionuclides to diffuse back through a leaking cell intake filter or manipulator boot. The area of maximum release potential due to ventilation failure is the dissolving cycle in B-Cel1 where up to $100 \mathrm{~kg}$ of fuel may be dissolved at one time. The cycle duration is 8 hours. However, the majority of the volatile fission products released are assumed to be driven off within the first few hours (90\% within 4 hours). By conservatively assuming $100 \%$ of the ${ }^{85} \mathrm{Kr}(1060 \mathrm{Ci})$ and $10 \%$ of the ${ }^{3} \mathrm{H}(6.7 \mathrm{Ci})$ as tritium gas (at least $90 \%$ of the ${ }^{3} \mathrm{H}$ is in the oxide form and would tend to go with the aqueous streams) are released to the cell $\left(510 \mathrm{~m}^{3}\right)$ and, consequently, to the work area $\left(813 \mathrm{~m}^{3}\right)$, the airborne concentration would eventually reach $8 \times 10^{-1} \mu \mathrm{Ci}{ }^{85} \mathrm{Kr} / \mathrm{CC}$ and $5 \times 10^{-3} \mu \mathrm{Ci}{ }^{3} \mathrm{H} / \mathrm{CC}$ in the operating and services galleries. These concentrations are $8 \times 10^{4}$ times the occupational MPC for ${ }^{85} \mathrm{Kr}$ and $10^{3}$ times the occupational MPC for ${ }^{3} \mathrm{H}$. Persons occupationally exposed to these concentrations for 5 minutes would receive total doses of 0.2 rem whole body and 22 rem to the skin. A release of this magnitude would obviously activate the Radiation Area Monitor alarms, resulting in evacuation of the building to minimize employee exposure.

This material would gradually diffuse to the outside and can thus be considered as a ground level release to the environment of $1060 \mathrm{Ci}$ of ${ }^{85} \mathrm{Kr}$ and $6.7 \mathrm{Ci}$ of ${ }^{3} \mathrm{H}$. If the release is considered to occur over a period of a few hours, the resulting offsite population dose potentials are shown in Table 6. The estimated whole body dose is just $2 \%$ of the 10 CFR 50 , Appendix I, Guide For As Low As Practicable (ALAP) releases to the atmosphere. 
TABLE 6. Ventilation System Failure Dose Estimates

$$
\text { Inhalation Doses (Tritium) }
$$

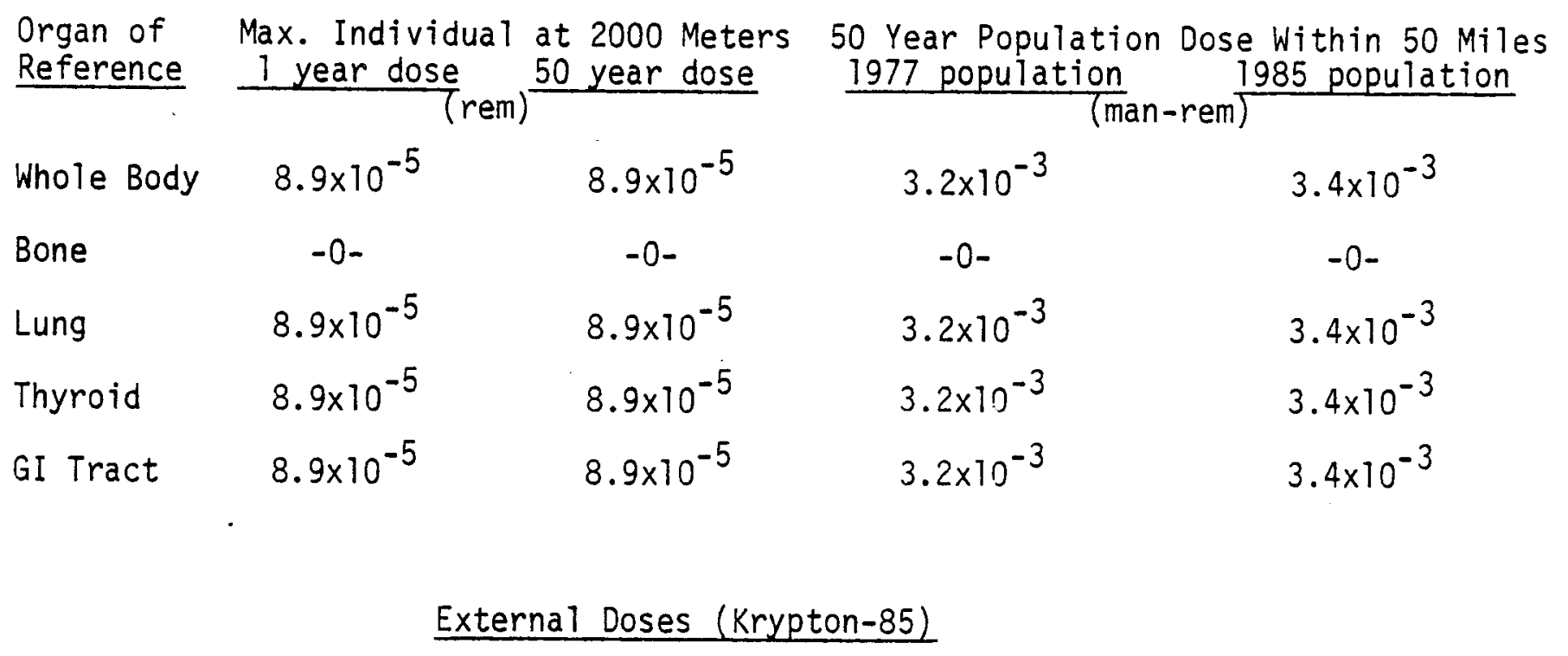

Max. Individual at 2000 meters
individual dose

(rem)

Whole Body

Skin
$3.0 \times 10^{-5}$

$1.2 \times 10^{-2}$
Population Dose Within 50 Miles 1977 population 1985 population

$$
\text { (man-rem) }
$$


The probability of this postulated accident would inciude the expected frequency of three independent belt-driven fans failing on the same day $\left(5 \times 10^{-7} / \mathrm{yr}\right)^{(13)}$ and the failure of both primary and emergency electrical power at the same time $\left(1 \times 10^{-4} / \mathrm{yr}\right) .(14)$ In this case complete electrical failure is the more likely cause of complete ventilation failure and, consequently, a release by this means would be expected to have a failure frequency of less than $10^{-4}$ /year.

\subsubsection{Cask/Fuel Unloading Accident}

DOT approved casks will be used to ship spent fuel elements to the 324 Building. While the casks remain sealed there are no credible accidents which will cause the release of radioactive materials. These casks will be unloaded in the Air Lock of the 324 Building Radiochemical Engineering Cells. The operations involved include loading the cask on a small dolly and transferring it into the Air Lock, removal of the cask's 7id, and transfer of the fuel elements by jib crane from the cask to metal thimbles for storage and handling.

The cask handling operation involving the greatest potential for radionuclide release is the transfer of a fuel element by jib hoist from the cask to a fuel thimble. For purposes of this analysis it is assumed that a PWR fuel assembly, containing $450 \mathrm{~kg}$ of uranium as $\mathrm{UO}_{2}$, while being unloaded, is broken in half through the incorrect operation or mechanical failure of the jib hoist. If this assembly is fractured while being lifted out of the cask it will be approximately $17 \mathrm{ft}$ above the Air Lock floor. It is highly unlikely that the jib hoist horizontal motion would be able to fracture either a BWR or PWR element, or that the fractured tubes of an element would be able to release more than a few pellets. However, for this analysis it is assumed that the majority of fuel pellets are released and fall the 17 feet to the concrete floor of the Air Lock.

It is postulated that a maximum of $1 \%$ of the solid material composing the fuel pellets is converted into powder by this action. Experimental evidence indicates that a maximum of $0.5 \%$ of a source of finely divided plutonium dioxide powder becomes airborne at airflows less than $100 \mathrm{~cm} / \mathrm{sec}$. (13) 
Therefore, a maximum of $0.005 \%(22.5 \mathrm{~g})$ of the solid radioactive material in a fuel element is assumed to become airborne. Assuming a $3 \times 10^{-7}$ transmission factor for these two HEPA filter banks, ${ }^{(12)}$ then $6.75 \times 10^{-6}$ grams $(15.8 \mu \mathrm{C} i$ ) of mixed fission and fuel products are released to the environment in particulate form. In addition, it is conservatively assumed that all of the ${ }^{85} \mathrm{Kr}(4800 \mathrm{Ci})$, and $10 \%$ of the ${ }^{3} \mathrm{H}(30 \mathrm{Ci})$ and ${ }^{129} \mathrm{I}\left(1.7 \times 10^{-2} \mathrm{Ci}\right)$, are released at the same time. No cleanup factors are postulated for these three radionuclides. The resulting dose potentials are shown in Table 7 . The estimated whole body dose is $4.0 \%$ and the thyroid dose $13 \%$ of the 10 CFR 50 , Appendix I, Guide for ALAP releases to the atmosphere. An occurrence probability of $2 \times 10^{-6}$ per year was established for this accident based on the recurrence rate of the activity and on industrial equipment failure data. 
TABLE 7. Cask/Fuel Unloading Accident Dose Estimates

\section{Inhalation Doses (Fission and Fue? Products)}

\begin{tabular}{|c|c|c|c|c|}
\hline $\begin{array}{l}\text { Organ of } \\
\text { Reference } \\
\end{array}$ & $\begin{array}{l}\text { Max. Indivi } \\
1 \text { year dos }\end{array}$ & $\begin{array}{l}\text { at } 2000 \text { Meters } \\
50 \text { year dose }\end{array}$ & \multicolumn{2}{|c|}{$\begin{array}{l}50 \text { Year Population Dose Within } 50 \text { Miles } \\
\frac{1977 \text { population }}{\text { (man-rem) }}\end{array}$} \\
\hline Whole Body & $1.0 \times 10^{-4}$ & $1.0 \times 10^{-4}$ & $3.1 \times 10^{-3}$ & $3.3 \times 10^{-3}$ \\
\hline Bone & $1.6 \times 10^{-7}$ & $1.6 \times 10^{-6}$ & $4.9 \times 10^{-5}$ & $5.2 \times 10^{-5}$ \\
\hline Lung & $1.2 \times 10^{-4}$ & $1.2 \times 10^{-4}$ & $3.7 \times 10^{-3}$ & $3.8 \times 10^{-3}$ \\
\hline Thyroid & $2.0 \times 10^{-3}$ & $2.4 \times 10^{-3}$ & $7.1 \times 10^{-2}$ & $7.5 \times 10^{-2}$ \\
\hline GI Tract & $1.0 \times 10^{-4}$ & $1.0 \times 10^{-4}$ & $3.1 \times 10^{-3}$ & $3.3 \times 10^{-3}$ \\
\hline
\end{tabular}

\section{External Doses (Fission and Fuel Products)}

Max. Individual at 2000 Meters Population Dose Within 50 Miles individual dose

$$
\text { (rem) }
$$

Whole Body

$7.8 \times 10^{-5}$

$1.4 \times 10^{-2}$
1977 population 1985 population

(man-rem)
$4.6 \times 10^{-3}$

Skin

$4.5 \times 10^{-3}$ 


\section{REFERENCES}

1. F. Swanberg, Jr., Safety Analysis Report, Chemical and Materials Engineering Laboratory, 324 Building, BNWL-CC-2028, Battelle, Pacific Northwest Laboratories, Richland, WA, February 17, 1969.

2. J. M. Taylor and F. M. Simonen, Safety Analysis of Transporting Radioactive Materials Associated with the CNWVP, Battelle, Pacific Northwest Laboratories, Richland, WA, October 1976.

3. United States Energy Research and Development Administration, Environmental Impact Assessment, Commercial Nuclear Waste Preparation Task, EIA/WPR/77, February 1977.

4. J. L. McElroy, K. J. Schneider, J. N. Hartley, J. E. Mendel, G. L. Richardson, R. W. Mckee and A. G. Blasewitz, Waste Solidification Program Summary Report, BNWL-1667, vol. 11, Battelle, Pacific Northwest Laboratories, Richland, WA, June 1972.

5. J. L. McElroy, Analysis of 324 Building B-Cell Safe Standby Layaway, BNWL-B-96, Battelle, Pacific Northwest Laboratories, Richland, WA, May 21, 1971.

6. "WHC/BNW Joint Occupancy Procedure," June 1, 1976.

7. The Savannah River Laboratory, The Composite Quarterly Report, Light Water Reactor Fuel Recycle, October-December 1976, DPST-LWR-76-2-4.

8. United States Energy Research and Development Administration, Final Environmental Statement, Waste Management Operations, Hanford Reservation, Richland, Washington, ERDA-1538, National Technical Information Service, Springfield, VA, December 1975.

9. J. J. Fix, Environmental Surveillance at Hanford for CY-1974, BNWL-1910, Battelle, Pacific Northwest Laboratories, Richland, Washington, 1975.

10. D. R. Speer, J. J. Fix, P. J. Blumer, Environmental Surveillance at Hanford for CY-1975, BNWL-1979 Rev., Battelle, Pacific Northwest Laboratories, RichTand, Washington, 1976.

11. Federal Register 40 23420, May 29, 1975, Environmental Radiation Protection for Nuclear Power Operations, Environmental Protection Agency, Proposed Standards (40 CFR 190).

12. E. E. Oscarson, J. Mishima, D. A. Waite, Detailed Accident Analysis for the High Level Waste Preparation Phase of the Commercial Nuclear Waste Vitrification Program, BNWL-2207, Battelle, Pacific Northwest Laboratories, Richland, WA, January 1977. 
13. J. M. Selby, et al., Considerations in the Assessment of the Consequences of Effluents from Mixed Oxide Fuel Fabrication Plants, BNWL-1697, BattelTe, Pacific Northwest Laboratories, Richland, WA, June 1975.

14. USAEC Division of Operational Safety, Operational Accidents and Radiation Exposure Experience, 1943-1970, WASH-1192, Fa17 1975. 


\section{DISTRIBUTION}

No. of

Copies

OFFSITE

1 ERDA Chicago Patent Group 9800 South Cass Avenue Argonne, IL 60439

A. A. Churm

27

ERDA Technical Information Center

\section{ONSITE}

1 ERDA Richland Operations Office

Programs Division

L. J. Adams

R. D. Fogerson

R. B. Goranson

R. D. Hudson

H. E. Ransom

4 R. P. Saget

F. R. Standerfer

M. W. Tiernan

\section{Battelle-Northwest}

B. V. Anderson

W. J. Bjorklund

W. F. Bonner

C. L. Brown

G. H. Bryan

J. R. Carrel1

J. W. Finnigan

J. C. Gibson

H. L. Henry

E. R. Irish

J. H. Jarrett

B. 0. Kahle

D. E. Knowlton

S. J. Kostowroski

H. V. Larson

R. A. Libby

J. L. MCElroy
No. of

Copies

R. E. Nightingale

E. E. Oscarson

C. R. Richey

W. D. Richmond

D. H. Siemens

H. W. Slater

J. L. Swanson

D. A. Waite

E. J. Wheelwright

H. H. Van Tuy 7

N. G. Wittenbrock

Technical Information Files (5)

Technical Publications (1)

HEDL

G. J. Alkire

J. K. Anderson

P. B. Bourne

R. 0. Budd

W. L. Bunch

G. 0. Carpenter

W. C. Craven

R. W. Dascenzo

J. T. Denovan

E. M. Johnston

F. J. Leitz

W. C. Mallory

L. A. Pember

W. E. Roake

G. J. Rogers

W. F. Sheely

D. E. Simpson

K. G. Toyoda

W. R. Wykoff 